\title{
RAOUL HAUSMANN'S REVOLUTIONARY MEDIA: DADA PERFORMANCE, PHOTOMONTAGE AND THE CYBORG
}

\author{
MATTHEW BIRO
}

Raoul Hausmann, the 'Dadasoph' and primary theorist of the Berlin dada movement, explored the impact of technology on the mind and body on a number of different levels in his art. This article argues that Hausmann's poetry and performance practices of 1918 and 1919 prepared the ground for the cybernetic imagery that became prevalent in his caricatures, photomontages and assemblages of 1920 - a type of imagery that continued to be featured prominently in his work well into the 1930s. Through an examination of Hausmann's poetry and performance strategies, his concept of human identity and his understanding of the relationship between sexuality and social revolution, a new understanding of Hausmann's visual concerns will be developed. In particular, this article will investigate why Hausmann's portraits often undermined their sitter's identity; why Hausmann sometimes emphasized sexuality in his representations; and why, in addition to reminding their viewers of mechanized war, Hausmann's images of the human-machine interface anticipated many of the ideas inherent in the concept of the cyborg developed in the latter part of the twentieth century.

Today, Berlin dada, the loosely knit German avant-garde art group active between 1918 and 1920, whose members included such artists and writers as Hausmann, Richard Huelsenbeck, George Grosz, John Heartfield, Hannah Höch and Johannes Baader, is recognized primarily for its development of montagebased aesthetic strategies such as assemblage and photomontage, techniques that located the creation of art in the activity of juxtaposing pre-existing, often massproduced materials. Viewed historically, as part of the historical avant garde, Berlin dada strategies have been acknowledged primarily not for the subject matter they treated, but rather for the transformative effect they had on the position and function of modern art in Europe in the early twentieth century. It is only more recently that their subjects - and the social, political and psychological issues that they represented - have come under scrutiny. ${ }^{1}$

By suggesting that a particular subject, the cyborg as a figure of modern hybrid identity, was central to the practices of a Berlin dada artist, I do not wish to 
de-emphasize the critical effect of Berlin dada art, the radical shocks that it first created through its (momentary) negations of meaning and its seeming destruction of all hitherto-existing Western conceptions of art during the early interwar period. Understood as 'anti-art', dada was recognized as 'ending' modern art through the revelation of art's institutions and the exposure of the groundlessness of artists' authority. At the same time, by suggesting that a particular subject was also important to the Berlin dada artists, I wish to identify a characteristic of the historical avant garde that has not yet been given the attention it deserves: namely, its radical identity politics. Since the 1960 s the montage- and media-based aesthetic of the historical avant garde has once again become popular in contemporary art. As will be argued here, the historical avant garde also anticipates the contemporary moment through its practices of imagining new forms of non-bourgeois, hybrid identity. ${ }^{2}$

The term 'cyborg' never appeared in Weimar culture. Indeed, the word was invented much later. Yet the term is useful, because it suggests how the interwar artistic and visual cultures of Germany anticipated many of the ideas that developed in the cultural discourses around the cyborg and cybernetics in the United States and Europe after the 1940s - discourses that were not merely theoretical, but practical and popular as well. The cyborgs that appeared during the Weimar Republic did not merely foreshadow the somewhat one-sided and uncritical first definition of the cyborg, articulated by Manfred E. Clynes and Nathan S. Kline in 1960 as a self-regulating human-machine hybrid: a sentient body altered biochemically, physiologically, or electronically so that it could live in environments for which it was not hereditarily suited. ${ }^{3}$ More significantly, the cyborgs of the Weimar Republic also predicted a number of more critical concepts attending the 'origin' and development of the field of cybernetics through the work of the mathematician Norbert Wiener and other scientists during the 1940s and early 1950s. Although Donna Haraway's theorization of the cyborg in the mid-1980s also helps to illuminate the development of the cyborg in Berlin dada art, the focus here will be primarily on Wiener's concepts. This is the case because, although aspects of Hausmann's cyborgs also evoke the still-more heterogeneous and 'postmodern' notion of identity that Haraway articulates (hybrid identity in its most radical form), Hausmann's more mechanistic understanding of subjectivity, developed through a critique of Freudian models, dovetails more closely with Wiener's conceptualization. ${ }^{4}$

Despite his pioneering role in cybernetics, Wiener did not coin the term 'cyborg'. He did, however, think deeply about the social implications of his scientific practices, and his writings on cybernetics and society describe very clearly specific effects on minds, bodies and societies that he believed the new field of cybernetics would help to bring about. While engaged in research for the US Military during the 1939-45 war, Wiener and his co-workers proposed cybernetics as an interdisciplinary field - one that was to unite scientists from different disciplines around problems of communication, control and statistical mechanics. ${ }^{5}$ Central to cybernetics as both a practical and a theoretical exercise was the development of numerical computers: machines that were binary, that depended on electronics rather than mechanical gears or relays, and that were entirely automatic for the length of the computing operation. ${ }^{6}$ Such computers, 
Wiener argued, could be used to form the central control systems of larger electro-mechanical assemblages designed to mimic complex human functions. ${ }^{7}$ These functions included tracking an enemy aircraft with anti-aircraft artillery or reading a text out loud. ${ }^{8}$

By proposing that complex human functions could be replicated by computational and mechanical systems, Wiener and his fellow scientists discovered a key for unlocking seemingly limitless amounts of instrumental power and complex control - 'slave labour', as Wiener called it, that could be made subject to human direction. ${ }^{9}$ In contrast to Clynes and Kline, the developers of cybernetics had no illusions that technological augmentation was always beneficial. Technology, they understood, also increased human beings' abilities to kill and enslave one another. ${ }^{10}$ Wiener argued that cybernetics was bringing about a 'second industrial revolution' through automation, one that held both enormous potential and terrifying danger. Although it would unleash undreamed-of productive power, it also had the potential to bring about a massive unemployment situation and to reduce the human labour force to the condition of slavery. ${ }^{11}$ Moreover, through the development of machines that automated human functions, human beings would become more interconnected - both within their societies and across them. Thus, as a result of the development of cybernetics in the context of the 1939-45 war, the cybernetically transformed human being was a figure that bound in a new and much more closely knit relationship the enemy 'other', conceived as the pilot in the Axis warplane, and the military 'self' or 'ally', conceived as the Allied anti-aircraft gunner. ${ }^{12}$ Cybernetic augmentation did not simply make humans both more powerful and at the same time more vulnerable. Despite - or perhaps because of - the division of world societies into groups of competing nations, cybernetic augmentation also made human beings much more interrelated and thus less able to say where the 'self' ended and 'others' began.

For Wiener, the cyborg was a figure that interrelated friend and enemy, self and other, because it was an entity that revealed human beings to be organisms that became what they were through learning and communication. Human beings, according to Wiener, learn more and display more adaptive behaviour than any other animal, a condition that stands as the source of their obvious strengths and position of dominance on the planet. ${ }^{13}$ Human identity does not consist of the matter out of which human beings are made - the 'stuff that abides', as he put it - but rather the 'patterns that perpetuate themselves', ${ }^{14}$ patterns that take the form of information that controls functioning, memory and development. ${ }^{15}$ Information, the same medium that made human beings like computers and machines, also made human beings more like one another. To recognize the cybernetic aspects of humans was thus to recognize their collaborative natures: that human beings are individuals created through processes of information exchange and implementation.

\section{THREE CYBORGS}

As suggested by two works that he exhibited at the First International Dada Fair in Berlin in the summer of 1920, the photomontage Self-Portrait of the Dadasoph (1920, 


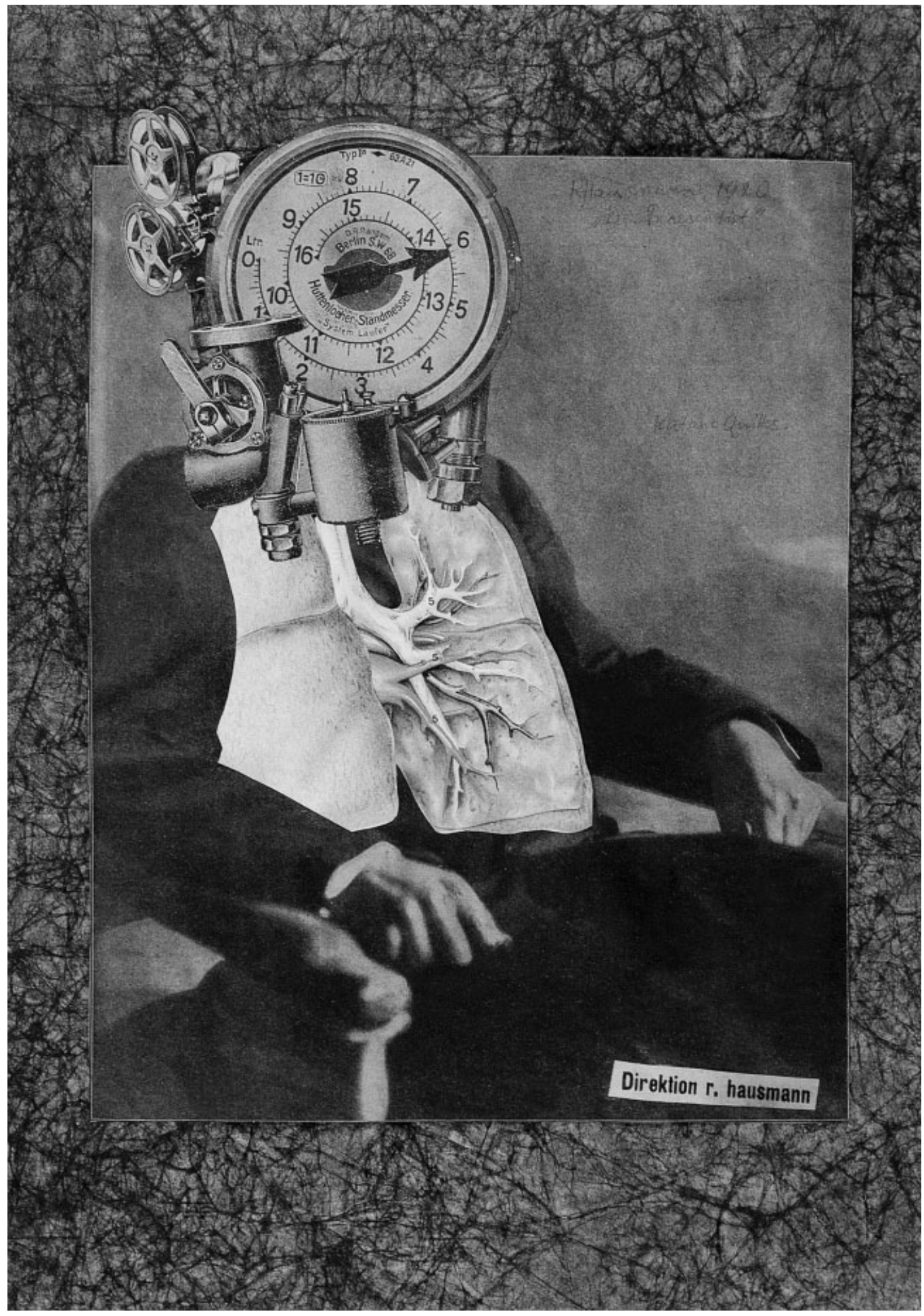

2.1 Raoul Hausmann, Self-Portrait of the Dadasoph, 1920. Collage and photomontage on handmade Japanese paper. $36.2 \times 28 \mathrm{~cm}$. Private Collection. Photo: (C) 2007 Artists Rights Society (ARS), New York/ADAGP, Paris. 
plate 2.1) and the ink drawing The Iron Hindenburg (1920, plate 2.2), Hausmann used the cyborg to represent the new hybrid human: a half-organic, halfmechanized figure that he believed was appearing with ever greater frequency in his modern world. As became the case with Wiener, Hausmann saw the cyborg as a figure through which images of both identity and difference could be formed. Self-Portrait of the Dadasoph presents a faceless cyborg wearing bourgeois clothing. It is identified as a self-portrait by the title listed in the catalogue of the First International Dada Fair, where the photomontage was first shown. The Iron Hindenburg, on the other hand, presents the cyborg as the enemy, the hated authoritarian militarist Field-Marshal Paul von Hindenburg, a figure

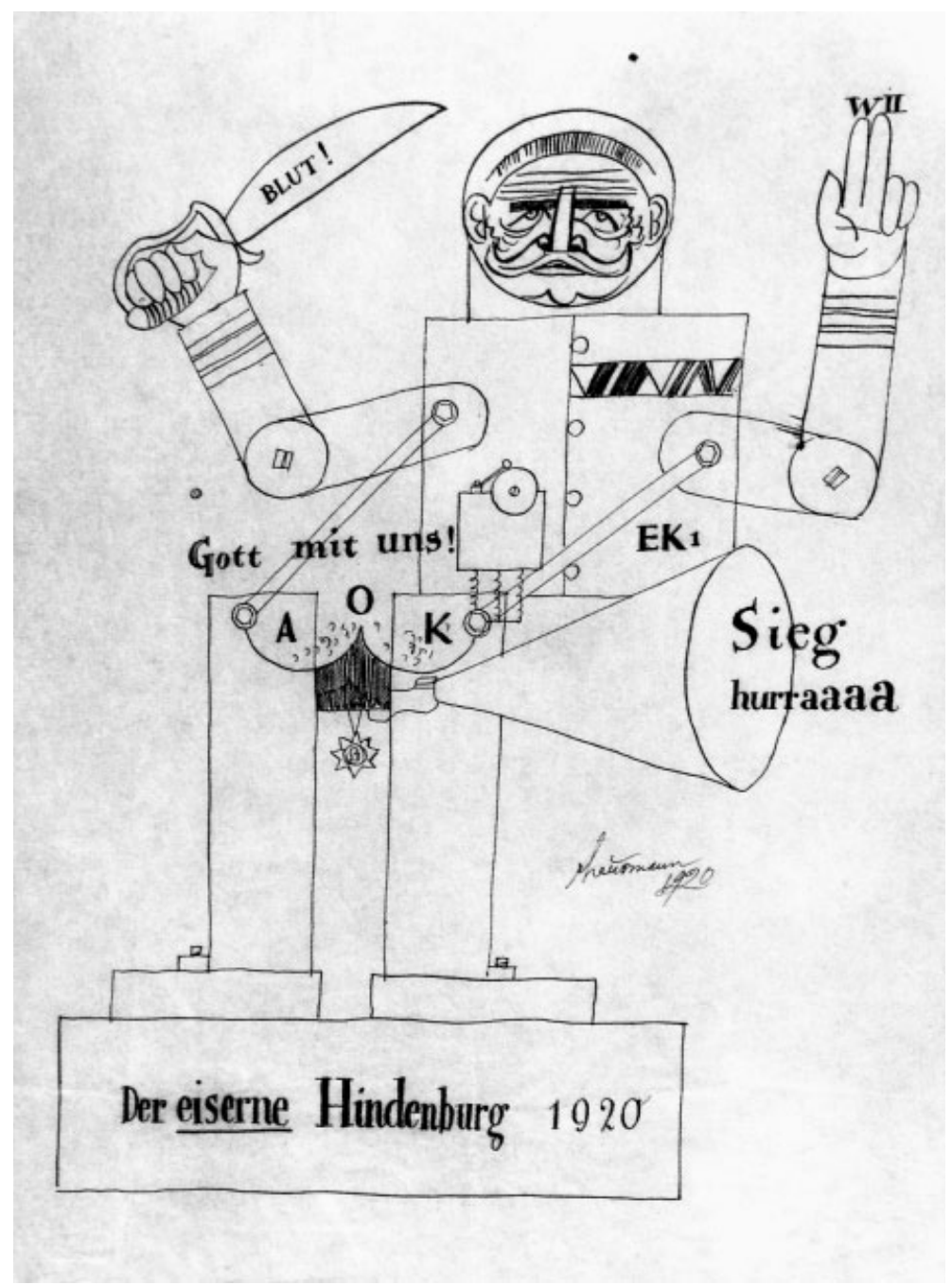

2.2 Raoul Hausmann, The Iron Hindenburg, 1920. Ink on paper. $40.6 \times 33.2 \mathrm{~cm}$. Paris: Musée national d'art moderne, Centre Georges Pompidou. Photo: (C) 2007 Artists Rights Society (ARS), New York/ADAGP, Paris. 
whose laughable and disgusting appearance could not disguise the fact that he remained a powerful and dangerous 'antipode' of the dada artists, one, moreover, who continued to act on behalf of the German military after the conclusion of the 1914-18 war. $^{16}$ By using the cyborg as a form that encompassed his own identity as well as that of his enemies, Hausmann suggested the fundamentally dialectical nature of modern existence, the fact that human identity was always a combination of 'own' and 'other' elements, as one of his intellectual influences, the psychoanalyst Otto Gross, put it. This dialectical, yet overarching, character of Hausmann's cybernetic representations anticipated the uneasy play between friend and enemy, self and other characteristic of Wiener's account of early cybernetics. In addition, as did Wiener, Hausmann's cyborgs implied that technological augmentation carried both extreme benefits and extreme risks.

The risks are perhaps easier to identify. In both representations, Hausmann sets up a traumatic continuum between organic and mechanical functioning. In the self-portrait, for example, the cyborg's pressure-gauge head seems to measure the energy that pumps through his body: a parodic anticipation of the focus on servo-mechanisms and feedback loops characteristic of Wiener's research. Although the rigidity of the figure expresses extreme tension and power, its head is put to a very mundane use; it lacks eyes, and its mechanical augmentation appears to have exposed its lungs. Moreover, the film projector that crowns Hausmann's head suggests that whatever rudimentary brain the cyborg still has left contains not thought but clichés - pre-digested cultural signs that the artist randomly re-circulates in his reified consciousness. ${ }^{17}$ Although the film projector also evokes the utopian view of the mass media characteristic of many cultural producers and theorists during the Weimar Republic, the fact that the cyborg appears to be blind suggests that - here, at least - the cyborg's cinematic thoughts circulate in a closed and repetitive circuit. For this reason, despite Hausmann's many positive statements about the mass media and the new ways of seeing afforded by science and technology, statements that link Hausmann to such other theorists as László Moholy-Nagy and Walter Benjamin, the conjunction of different photomontage elements in Self-Portrait of the Dadasoph (see plate 2.1) suggests an ambivalent attitude about the film projector. ${ }^{18}$ The fears that Hausmann sometimes expressed about science and technology, anxieties that emerged from his awareness of the uses to which they were put during the 1914-18 war, are clearly apparent in this representation, and they preclude the projector from functioning as a purely positive symbol. ${ }^{19}$

The portrait of Hindenburg, moreover, goes even further to emphasize the cyborg's dysfunctional nature. Expressing his hatred of German militarism, Hausmann displays the cyborg's body split open, its arms linked to its buttocks, its voice emerging from its genitals. Contrasting with its human face and hairy backside, the cyborg's body displays prominent mechanical grafts - the combination of loudspeaker and military medal that replaces its reproductive organs, for example. Through these grafts Hausmann expresses ambivalence about the ultimate benefits of technological enhancement; in addition to military capabilities, the speaker and medal amalgam also connotes castration. By presenting Hindenburg in this way, Hausmann alludes to the practice - carried 
out much more extensively in the dada photomontages, paintings and assemblages of George Grosz, John Heartfield and the Dresden-based Otto Dix - of employing the figure of the cyborg as a 'war cripple', and thus as a counter to the idealized image of the armoured male soldier, a figure that became popular during the 1914-18 war.

Nearly all the Berlin dada artists point to wartime visual culture as inspiring at least in part - their photomontage practices. ${ }^{20}$ (Cubist collage as well as the collage practices of the Italian futurists and the Zurich dada artists were the other influences acknowledged by some of them.) For Grosz and Heartfield, their development of photomontage as a fine art strategy in the late teens was motivated by their earlier practice of sending collaged postcards and care packages with anti-patriotic messages to one another during wartime. In these early works, none of which have survived, the ambiguity of the photomontage technique was employed to evade military censors. Moreover, as Brigid Doherty has demonstrated, this strategy also evoked the practices of wartime advertising as well as the organized production and sending of 'care packages' or 'gifts of love' [Liebesgaben] - 'albums composed of newspaper and magazine clippings, postcards, and reproductions of works of art' - by female volunteers to frontline soldiers during the war. ${ }^{21}$ Hausmann and Höch, on the other hand, directly refer to their contact with soldier portraits in the summer of 1918 as the experience that made them realize the various possibilities of photomontage as an artistic strategy. $^{22}$

Soldier portraits, which were produced by the thousand in the late nineteenth and early twentieth centuries, were idealized images of armoured male soldiers. ${ }^{23}$ Images that commemorated wartime service in both word and likeness, these portraits were purchased by soldiers to send home to loved ones, to celebrate a comrade's retirement from active duty, or for themselves after they returned from the war. The soldier would sit for a photographer, who would shoot a likeness of the soldier's head, and then cut and paste the finished photograph into a mass-produced lithographic image or some other form of readymade framework that depicted idealized uniformed bodies often positioned against military or heraldic backgrounds. On an ideological level, these materially hybrid images affirmed nationalist and militarist ideals. They were produced and consumed by individuals who were interested in glorifying and ennobling the military subject. For the most part, this meant making the soldier's unique physiognomy and readymade body conform to the values of the Prussian state, a state that wanted him to fight an enemy and possibly die - 'with God for King and Fatherland', as the popular saying went. Although the soldier portraits supported the interests of the German monarchy, they were not state propaganda. Instead they were mass-market commodities which catered to the psychological needs of a majority of Germans and, at the same time, helped to legitimate the existing political, economic and military - status quo.

Klaus Theweleit has analysed the psychology of the German soldier of this period in his monumental Male Fantasies, a study of the memoirs of various Freikorps officers, soldiers who served in the right-wing armies that fought the left in Germany during the first few years of the Weimar Republic. ${ }^{24}$ Many of these soldiers ended up serving the Nazi movement, and since its publication in the mid-1970s, Theweleit's study has come to be interpreted as one of the 
paradigmatic accounts of the psychology of the fascist male subject. ${ }^{25}$ According to Theweleit, the typical Freikorps officer manifested an undeveloped ego. He was afraid of his own desires as well as anything else that would cause his fragile sense of corporeal and psychic identity to be overcome. To shore up his fragile ego, the fascist subject fortified his body through physical drill, armour, weapons, and through the extermination of all forms of otherness that threatened his inchoate and fragile sense of self: in particular, women, Bolsheviks, Jews and the un-regimented mass. Afraid to acknowledge the personal, intimate and desiring aspects of his being, he furthermore sought solace in abstract concepts of the community - the troop, the army, the nation and the people (das Volk) - in whose name he destroyed that which he perceived as different from himself and thus a threat. It was only in acts of mobilization and killing that he could experience his own desires - acts that prevented him from recognizing these desires for what they really were and, moreover, that served to shore up the rigid distinctions through which he understood his world.

The soldier portraits that inspired Hausmann and Höch's development of photomontage as a dada practice fit very well with Theweleit's analysis of the German military subject in the early twentieth century. As suggested by numerous examples, the soldier portraits glorified the fighting man's figure by armouring it and making it look powerful. ${ }^{26}$ They accomplished this by building up the soldier's body through his idealized, mass-produced uniform, by equipping him with weapons, by representing him with an erect and vigilant posture, and by often situating him amidst a troop or set of identically dressed comrades in arms, ideologically committed 'brothers' who shared a single cause. Given this conjunction between the soldier portraits and the Wilhelmine and fascist military ideals, it is easy to see why the Berlin dada artists favoured both photomontage and the image of the cyborg as a war cripple in the early 1920s. Together, the strategy and the specific image type referred to, and undermined, the military ideal as represented by the soldier portraits. Typically, the dada images of war cripples broke down the armoured male body, portraying it as shattered, dysfunctional and uncontrollable, seething with instinct and unchecked desires. And although The Iron Hindenburg certainly embodies this aspect of the Berlin dada artists' practices - their attempts to use the cyborg to undermine the duplicitous military ideal that helped to lead Germany to ruin - it is important to note that the representation of war cripples is only one part of Hausmann's visual practice - and a small one at that. In contrast to Grosz, Heartfield and Dix, who all saw military service, Hausmann avoided the war, and afterwards he rarely used the cyborg to attack the figure of the armoured male soldier. Instead, in Hausmann's work, the cyborg - particularly as configured through photomontage - is far more frequently used to explore more the positive aspects of the technological enhancement of human beings, albeit not without a consistent admixture of ambivalence.

An example of this more positive representation of human - technological interface can be seen in the photomontage self-portrait $A B C D$ (plate 2.3). Here Hausmann presents himself more directly through a fragmented and frontal photographic portrait with an irregular and quasi-gear-like 'monocle' sutured over his left eye. Surrounding his truncated visage on all sides, the dada artist has pasted various photographic and photomechanically reproduced elements, 


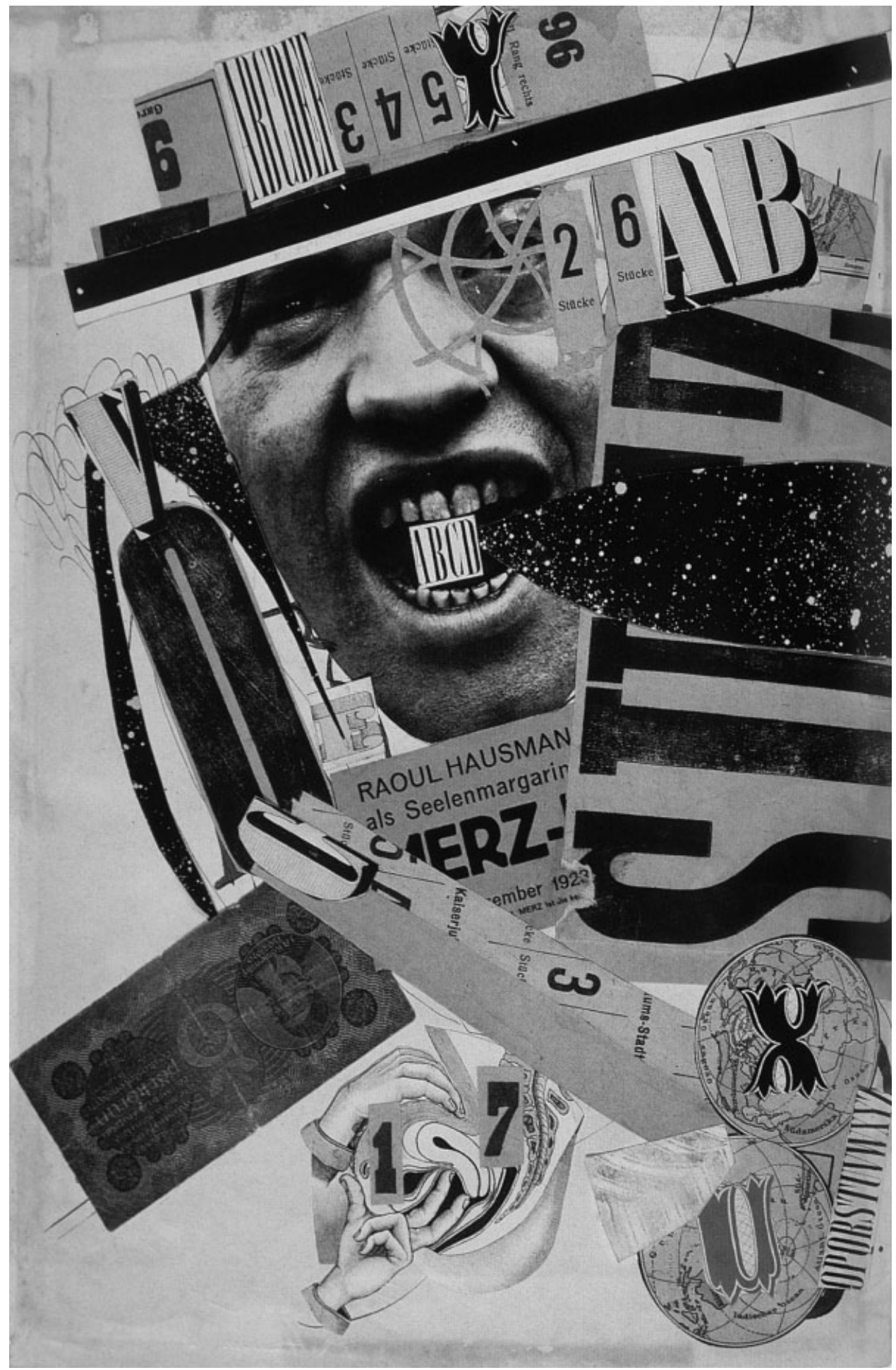

2.3 Raoul Hausmann, $A B C D, 1923-24$. Collage, $40.7 \times 28.5 \mathrm{~cm}$. Paris: Musée national d'art modern, Centre Georges Pompidou. Photo: (C) 2007 Artists Rights Society (ARS), New York/ADAGP, Paris. 
including numbered tickets, letters and letter rows evincing different typographical forms, pieces of maps, photographic fragments of a starry sky, an anatomical cross-section of a woman's pelvis, an upside-down Czech banknote, and (cutting off the bottom of Hausmann's chin) a fragment of an announcement designed by El Lissitzky for an optophonetic performance by Hausmann and Kurt Schwitters in Hannover in $1923 .{ }^{27}$ These photomechanical fragments, a profusion of equally arresting mass-reproduced elements, create larger constellations of meaning through which the transformative power of Hausmann's technologically augmented vision is suggested.

The power that Hausmann ascribed to cybernetic vision can first be seen at the level of the subject matter that is represented. It is implied by the emphasis and radiating motion that he gives to his left eye in conjunction with the various viewpoints implied by the image: the penetrating (male) gaze evoked by the crosssection of the woman's body as well as the more neutral scientific gaze evoked by the stretches of starry sky. When connected with the profusion of tiny map elements, these iconic fragments suggest points of view that tend to control the things they represent: points of view that can see below the surfaces of things; objectively document an important phenomenon for further study; and abstract from reality in order better to navigate and build within it. In addition, however, in conjunction with the number and letter rows (signs of classificatory practice that have been severed from their original context and thus rendered almost meaningless), Hausmann suggests that his cybernetic vision is also one that can confound or mix up all documentary and classificatory systems - a gaze that is potentially revolutionary. Hausmann thus represents his cybernetic vision as one that can fragment, transform and synthesize multiple realities and viewpoints, a vision that is powerful and potentially exploitative, but also potentially liberating.

This sense of transformative, controlling and liberating vision - vision as a constant process of analysis, synthesis and re-analysis - is further emphasized by the cyborg's photomontage form. A strategic counter to both formalist and expressive abstraction in the first two decades of the twentieth century, photomontage was a much emphasized signifier of Berlin dada's radicalism or newness. It represented their rejection of abstract painting as both a medium-specific and a subjectivist project and their affirmation that art had to take politics and modern life as its subject. In addition, as Hausmann later argued, because dada photomontage produced a form of sensory derangement - 'an explosion of viewpoints and a whirling confusion of picture planes', as he put it - photomontage was particularly well suited for examining dialectical relations between form and content. ${ }^{28}$ By assembling both appropriated and self-made fragments so that they could be read in terms of different constellations, Hausmann's photomontages formally provoked an experience of visual and linguistic ambiguity and engaged their audiences by encouraging them to free associate. The medium of photomontage was thus potentially empowering, suggesting, as it did, that how one saw could potentially affect and transform what one saw. It could, in other words, make its various audiences recognize their own contributions to their aesthetic experiences; and thus it could potentially influence them to take a more reflexive and critical attitude to both life and politics. Moreover, by simplifying the process of artistic representation and by suggesting that the artist was as much a recycler 
as a creator of images, photomontage also made the artist and the spectator more alike. Long before Joseph Beuys, dada photomontage implied that everyone was, indeed, an artist. Hausmann's cyborgs were thus designed to represent more than just a new dada self and other. In addition, they also attempted to constitute a new spectator - an audience whose growing desire for the play of meaning was to result in the creation of new modes of perceiving and acting in the world.

\section{HAUSMANN'S OPTOPHONETIC POETRY AND PERFORMANCE PRACTICES}

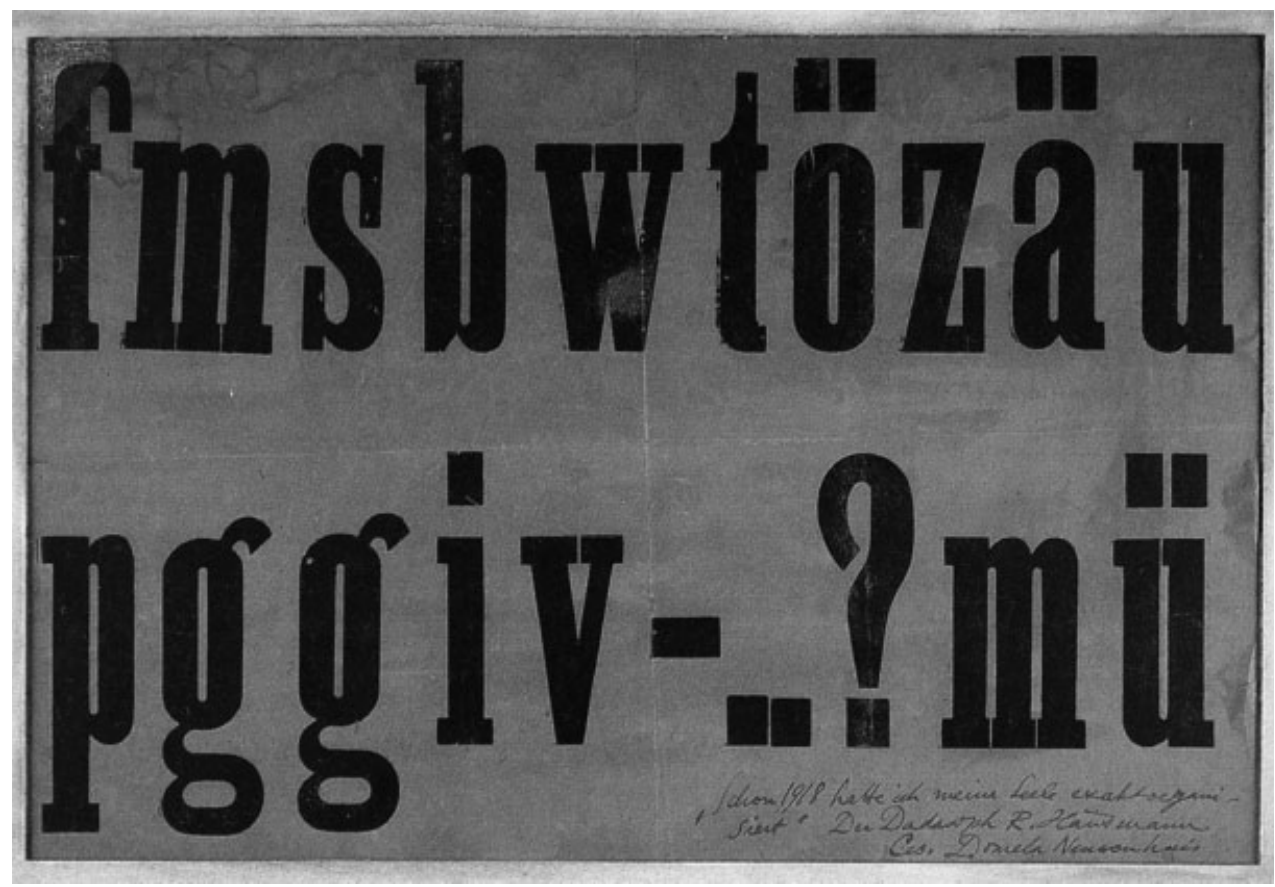

2.4 Raoul Hausmann, fmsbw, 1918. Poster poem. Print on brown paper, $33 \times 48 \mathrm{~cm}$. Paris: Collection? Madame Ruth Domela. Photo: (C) 2007 Artists Rights Society (ARS), New York/ ADAGP, Paris.

Because they refer to Hausmann's poetry and performance practices, $A B C D$ 's second major constellation of fragments, the number and letter rows, provide insight into the new form of spectator that Hausmann was attempting to create through his cybernetic photomontages. An acknowledgment of the cyborg's poetic and performative roots, these number and letter rows anticipated the focus in cybernetics in the 1940s and 1950s on exploring the various media of electrical, mechanical and biological communication. ${ }^{29}$ Hausmann clearly refers to his practice of optophonetic poetry through the letter and number rows. Not only does he present himself with his mouth open and a string of letters emerging from his lips, but he also directly advertises his collaborative performances with Schwitters through the Lissitzky poster. ${ }^{30}$ In addition, the large letter 
row amputating the left side of his face recalls the typeface of his poster poem fmsbw of 1918 (plate 2.4), a text that formed the basis of some of his performances. ${ }^{31}$ In accordance with dada ideology, poster poems like fmsbw were generated both by chance and collaboratively. As Hausmann tells it, he worked with a Berlin printer, Robert Barthe, who pulled the letters in a semi-random fashion until he filled up two horizontal rows. ${ }^{32}$ The letter rows were then printed on poster board, and the resulting art works were both exhibited and used as springboards for performances.

Like many other German artists and intellectuals at the time, Hausmann believed that the German language had degenerated and could no longer express authentic human experiences. Hausmann's optophonetic poetry was thus motivated by a utopian intention: it was designed to break language free of what he perceived to be its rational and conceptual straightjackets and to broaden his audiences' understandings of its multivalent potentials. Although it was developed in a context in which numerous experiments with language were being carried out, it was significantly different from other contemporary explorations. ${ }^{33}$ First, Hausmann's use of chance in conjunction with the brevity of his unit of selection - the single letter - eliminated all or almost all semantics. Hausmann's poster poems thus differed from the work of such Zurich dada sound poets as Hugo Ball and Tristan Tzara as well as the expressionist Wortkunst poet August Stramm, because Hausmann's poster poems no longer used words, let alone phrases. ${ }^{34}$ For the same two reasons (the use of chance and the emphasis on the single letter), Hausmann's poetic texts were also different from the works of such other important precursors as the Russian zaum poets, Velimir Khlebnikov and Alexei Kruchenykh, as well as the Italian futurist poets, such as F. T. Marinetti and others, all of whom demonstrated greater semantic content in their writings. ${ }^{35}$ Viewed in relation to his contemporaries, Hausmann's innovation in the context of avant-garde poetry was his treatment of letters - as opposed to words or syllables - as the basic units of language. Poetic metaphor was thus avoided, although the expressive significance of the voice was retained. In addition, the bunching up of consonants as well the inclusion of pictographs and punctuation symbols that could not in themselves be spoken out loud created vocalization and articulation problems. In this way, gaps or breaks were made part of the performance and the possibility of slips of the tongue was increased. Finally, the letter was simultaneously treated as an optical and an acoustic sign. 'Different sizes', Hausmann insisted, 'receive different intonations. 36

By exploring the basic materials of human language - letters and sounds - in a way that sought to establish new affinities, Hausmann believed that he was helping his society to overcome the constrictions placed on language through its increasingly efficient and rationalized development. Montages of instantly readable forms, Hausmann's poster poems were generated automatically and collaboratively in such a way as to deny almost all semantic content. Hausmann's poetry thus undermined the individuality of the poetic 'author' and negated many of the traditionally 'subjective' aspects of poetry. Instead, it potentially focused its audiences' attentions on affect and instinctual content as well as the highly conventional, complex and almost unrecognizable aspects of everyday life, namely, basic forms of communication. 
Hausmann recreated his optophonetic performances in several recordings between 1956 and 1966 - recordings that indicate what Hausmann's original performances must have been like. These performances are generally short (under four minutes), waver between song and speech, and, as one critic put it, appear to nourish themselves 'out of an unconscious condition'. ${ }^{37}$ Sometimes accompanying himself with rhythmic beats from a wooden box or cardboard tube, Hausmann sings and speaks in short repetitive phrases. As suggested by his recordings of fmsbw and other poems, which merge phrases or letter rows from different posters, Hausmann improvised on his poster poems when performing them out loud. And as the transformation of the poster poems from the written to the spoken word indicates, Hausmann employed montage and chance procedures on multiple levels in his poetic works, thereby increasing their cut-up and fragmented character. Like Schwitters - who appropriated the primary theme of his Ur Sonata (1922-32), 'Fümms bö wö tää zää Uu, pögiff, kwii Ee', from fmsbw and OFFEAH (1918), another poster poem by Hausmann - Hausmann edited and recombined his various letter rows, repeating them with different rhythms, tones and other variations. ${ }^{38}$ Over the course of his recitals, Hausmann's voice changes in volume and pitch and evokes a range of different vocal qualities, including stuttering, throat-clearing, hissing, snarling, whispering and wheezing. In the more speech-like passages, the associative qualities of Hausmann's performances change radically. At times it seems as if Hausmann is speaking rationally in some unknown foreign language; at other times it seems as if Hausmann's speech expresses the more instinctual drives of a deranged or child-like mind. At still other moments, Hausmann sounds as if he is speaking in tongues. In contrast to Schwitters's more classically musical approach, Hausmann's performances demonstrated a greater interest in improvisation and the exploration of psychological content.

As suggested by his poster poems and the recordings of his optophonetic performances, Hausmann's original dada performances shocked and confronted their audiences by combining formalist and reflexive concerns with psychological ones. ${ }^{39}$ By breaking down the material of spoken and written language into their smallest components and by evoking associations of madness and religious ecstasy as well as childhood states and conflicts, his performances could - and sometimes did - inspire his audiences to examine their own psychic construction through linguistic and social forces. Of course, it is difficult to ascertain how close Hausmann's reconstructions came to his original performances. At the same time, the historical record indicates that strong continuities existed. One contemporary observer, Hans Richter, described Hausmann's performative technique as extremely shocking and confrontational: 'Hausmann always gave the impression that he harbored a dark menacing hostility to the world. His extremely interesting phonetic poems resembled, as he spoke them, imprecations distorted by rage, cries of anguish, bathed in the cold sweat of tormented demons. ${ }^{40}$ In addition, many of the original performers and audience members have written that emotional, often violent audience reactions were common at the dada performances. ${ }^{41}$

Influenced by diverse sources including the Italian futurists, Paul Scheerbart, Christian Morgenstern, Richard Huelsenbeck, August Stramm and Wassily Kandinsky, among others, and anticipating French dictature lettriste after 1945, as 
well as concrete and Fluxus poetry, Hausmann's compositional and performance strategies were fundamentally interrelated. ${ }^{42}$ At the heart of these strategies lay Hausmann's avant-garde interest in opening up the historical and expressive potential of his artistic materials and exploring the formal and psychic contexts in which human beings develop their identities. As $A B C D$ suggests, the figure of the cyborg - especially as configured through photomontage - continued this confrontational challenge from artist to audience to reflect collectively on the linguistic, social and libidinal construction of subjectivity and alterity, identity and difference. It was only by collaborating with his audiences to break down traditional forms of identity through poetry and performance during the first eighteen months of the Berlin dada movement, that Hausmann could later arrive at the form of the cyborg as a dialectical figure in which self and other, friend and enemy, artist and audience found new forms of connection, interrelation and comparison.

\section{HAUSMANN'S UNDERSTANDING OF HUMAN IDENTITY}

That Hausmann would eventually arrive at the figure of the cyborg as a dialectical figure interrelating self and other, artist and spectator, is not surprising given the parallels between Hausmann's understanding of human identity and that of Wiener. According to Wiener, both humans and machines were essentially gatherers, manipulators and producers of information. Their actions were based on received messages that programmed their activities - albeit in a manner that could potentially be altered on the basis of further learning. ${ }^{43}$ For these reasons, machines and humans were fundamentally commensurate, and they could be combined with one another in an ever-expanding number of ways. ${ }^{44}$ As a closer look at Hausmann's thinking on the subject reveals, the creation, transmission and reproduction of information was also central to Hausmann's understanding of what it meant to be human.

Hausmann's concept of human identity was strongly influenced by the radical psychoanalyst Otto Gross and the anarchist thinking of The Free Street, a journal edited by Franz Jung, among others, to which Hausmann contributed in the late teens. ${ }^{45}$ Gross, a renegade student of Freud, believed that psychoanalysis could provide humans with a means of dismantling once and for all the ossifying bourgeois social and family orders and of building a new anarchist society based on individual liberty and sexual freedom. Like Freud, Gross traced individual neuroses back to the suppression of unresolved conflicts between a person's drives and what Freud later called his or her super ego, the representative of the social order within the individual psyche. And like Freud, Gross saw childhood and adolescence as the crucial times during which the psyche and an individual's sexuality were formed. Unlike Freud, however, Gross did not uphold the traditional path of establishing sexual identity in the context of the patriarchal bourgeois family, a path that constrained the infant's original polymorphous perversity by training it as a child and as an adolescent to pursue only heterosexual and monogamous relationships. Instead, Gross argued that the patriarchal family structure itself was the source of all individual and social neurosis and that the psyche's original heterogeneity had to be rediscovered. Psychoanalysis had to be used to rethink the relations between 'own' [das Eigene] and 'other' [das 
Fremde]: between an individual, heterogeneous and shifting instinctual core and social role models imposed by a person's family and the larger social context of which he or she was a part. ${ }^{46}$

Hausmann adapted Gross's theory of human identity in a series of articles on social revolution published in the radical journal The Earth in $1919 .{ }^{47}$ In 'On World Revolution', for example, he argued that despite the partial breakdown and seeming bankruptcy of the old monarchical and bourgeois social orders in the wake of the 1914-18 war, the transformation of human sexuality was a necessary precondition for the development of new non-hegemonic modes of communal life. ${ }^{48}$ Hausmann identified the old bourgeois world order with a radically hierarchical and dominating form of ideology, one moreover that he saw as characteristically male. Reinforced by the family, the economy and the state, this essentially individualistic, hyper-rational, capitalist and heterosexual ideology repressed alterity or difference and attempted to regulate everything and everyone in its environment. Because it related to all things by trying to dominate them, the patriarchal ideology, Hausmann believed, was ultimately suicidal. In the short run, however, it possessed tremendous power, and it caused reality to submit to its rigid concepts and distinctions. ${ }^{49}$

In Hausmann's account, bourgeois subjectivity was fundamentally defined, not through its class structure and economic relationships of ownership and production (as was the case in Marxist and communist theory), but rather through its sexuality. For this reason, in order for the new human and community to develop themselves, the heterosexual male system of values had first to be overcome. Homosexuality, which Hausmann viewed as a natural drive present at all stages of human libidinal development, was one way to overcome the heterosexual male drive to secure property, order and the subjugation of others. ${ }^{50}$ Promiscuity, the surmounting of monogamy, was another way in which this dominant system of individual and social values could be overturned. It was, however, ultimately women and their sexual practices who would define the new human and the new society. ${ }^{51}$ Although Hausmann never developed these insights into anything resembling an elaborated theory - and, indeed, although his own personal actions sometimes seemed to contradict his more progressive statements - it is clear that he believed that human beings could transform themselves by paying greater attention to their instinctual drives and by emulating non-dominant forms of gender identity. ${ }^{52}$

As suggested by his writings for The Earth, Hausmann conceptualized modern identity according to social and psychological models. He appears to have understood the modern subject to be a semi-autonomous ego, produced through and then eventually directing the interaction of social and instinctual forces. The subject was both socially constructed - taught by the family, social and educational groups, the state and the media - and transformable; that is, it did not simply have to repeat the roles that it had learned, but could creatively vary its practices and thus change itself. Even a person's sexuality, Hausmann argued, was potentially subject to alteration, nor did it need to remain stable over time. In contrast to Wiener's more-mechanistic understanding of human identity as essentially a function of received and manipulated information, Hausmann's conceptualization tended to emphasize to a much greater degree the corporeal and instinctual aspects of human beings. In addition, because he also emphasized 
the slips and gaps in inter-human information exchange far more than did Wiener, Hausmann's model of identity also seems to allow for a concept of subjectivity that involves a moment of misrecognition, an identification of the self with an ideal that, instead of reproducing the same, introduces novelty.

At the same time, however, it is important not to forget the somewhat fixed and mechanistic view of subjectivity inherent in the Freudian models of the human psyche from which Hausmann developed his own concepts. Although he radically criticized and reformulated Freud's account of identity under the influence of Otto Gross, Hausmann stressed the importance of Freudian concepts for the development of dada art throughout his life. ${ }^{53}$ Thus, although aspects of Hausmann's model of identity anticipate the radical critique of the subject characteristic of post-Freudian psychoanalysis - as can be found, for example, in the writings of Jacques Lacan - the idea of the subject as completely fictional is absent from Hausmann's writings, a result perhaps of Hausmann's very limited understanding of the processes of identification. Moreover, as was to become the case for Wiener, information, for Hausmann, was key. The identity of human beings depended upon how their instinctual energies were expressed, and the expression of these energies, in turn, depended on the scripted behaviours that they learned from their parents and from others in their societies - even if they could misread them, and thus learn them improperly. As was the case for Wiener, human beings for Hausmann had machine-like aspects because they were fundamentally shaped by the messages that they received. And it was probably for this reason that Hausmann emphasized child-like states in some of his performances - thereby evoking the period in human existence during which the majority of human behaviour is programmed - for it was in this way that he could provoke his audiences to reflect on the developmental contexts in which their personalities were first formed. It was also probably for this reason that Hausmann focused on the fundamental components of written and spoken language, for it was in this way that he could get his audiences to examine two of the primary mediums through which their behaviours were encoded and passed on.

\section{THE CYBORG AND PORTRAITURE}

As the parallels between Wiener's theories and those of Hausmann suggest, Hausmann's dada cyborgs were intended to represent the radically hybrid and collaborative nature of human identity in modern societies. They revealed that modern subjectivities were socially and collectively produced, and that the communal scripts they followed came from a multiplicity of conflicting sources. As has already been suggested through the analysis of The Iron Hindenburg (see plate 2.2), Hausmann saw his enemies or antipodes as radically hybrid like himself. Moreover, as was suggested by self-portraits such as Self-Portrait of the Dadasoph (see plate 2.1), an image that uses the awkward body of Gustav Noske, the Weimar Republic's first Minister of Defence, in place of the artist's own body, Hausmann recognized his kinship with the modern personalities that he most opposed. ${ }^{54}$ 
Because they represented an extremely de-centred or hybrid form of human identity, Hausmann's cybernetic portraits often undermined a number of the standard functions of portraiture. By Hausmann's time, the portrait had long been used - both in painting and in photography - as a means of celebrating the uniqueness of human identity. Often used to signify status, convey personality, or mark a moment in the development of a particular life, many forms of photographic and painterly portraiture claimed to present a truth that was both ontological and subjective. Both painterly and photographic portraits claimed, in other words, that a particular individual existed, and, moreover, that the particular forms that the portrait depicted were signs revealing the sitter's specific personality, psyche or fate. And in this way, despite the representational conventions that were observed to creep into all forms of portraiture (conventions that suggest that the sitter is, in certain ways, like a number of others), the portrait subject's 'individuality' - his or her specific existence and character - has often been stressed by the genre of portraiture. However, as suggested by two more cybernetic portraits by Hausmann, images of artists with whom he clearly identified, this stabilizing and individualizing effect that is often produced by painterly and photographic portraiture is much less pervasive in the portraiture that appears in dada art.

As can be seen in both Tatlin Lives at Home (plate 2.5), a close-up 'portrait' of the Russian artist Vladimir Tatlin, with whom the dada artists connected the progressive and aesthetically liberating tendencies of what they called the new 'machine art', 55 and Elasticum (plate 2.6), Hausmann's ironic homage to his fellow dada artists, Francis Picabia and Hans Arp, the cyborg also served as a positive role model for Hausmann - something that he was later able to represent more directly in his self-portrait $A B C D$. Significantly, neither of these two works contains photographic representations of the named artists and, thus, unlike $A B C D$, they are not portraits in the sense of iconically representing their subjects. According to Hausmann, 'Tatlin' received the head of an 'unknown man' that Hausmann found in an American magazine and whose features he associated with the Russian artist for reasons he could never explain. ${ }^{56}$ The source of the head in Elasticum, on the other hand, has never been revealed, although its features are definitely not those of either Picabia or Arp. Indeed, the unknown head looks much more like Henry Ford, the world-famous American inventor and businessman, whom the dada artists associated with the assembly line and mass-production techniques. ${ }^{57}$

Rather than reproducing the features of their professed subjects, 'Tatlin' is identified by the title of the photomontage listed in the catalogue of the First International Dada Fair and 'Picabia/Arp' by textual puns situated within the image field. The identities of the dada artists are thus rendered unstable and the spectator is encouraged to associate the 'dadaism' of the two figures with the machinery and the other objects with which they are connected as well as the fragmented and dialectical way in which they are composed. And precisely because of their anonymity, they can represent Hausmann or the other dada artists as much they do their ostensible subjects. These portraits are thus both individual and collective; they represent particular artists as well as more general prototypes of a new collaborative 


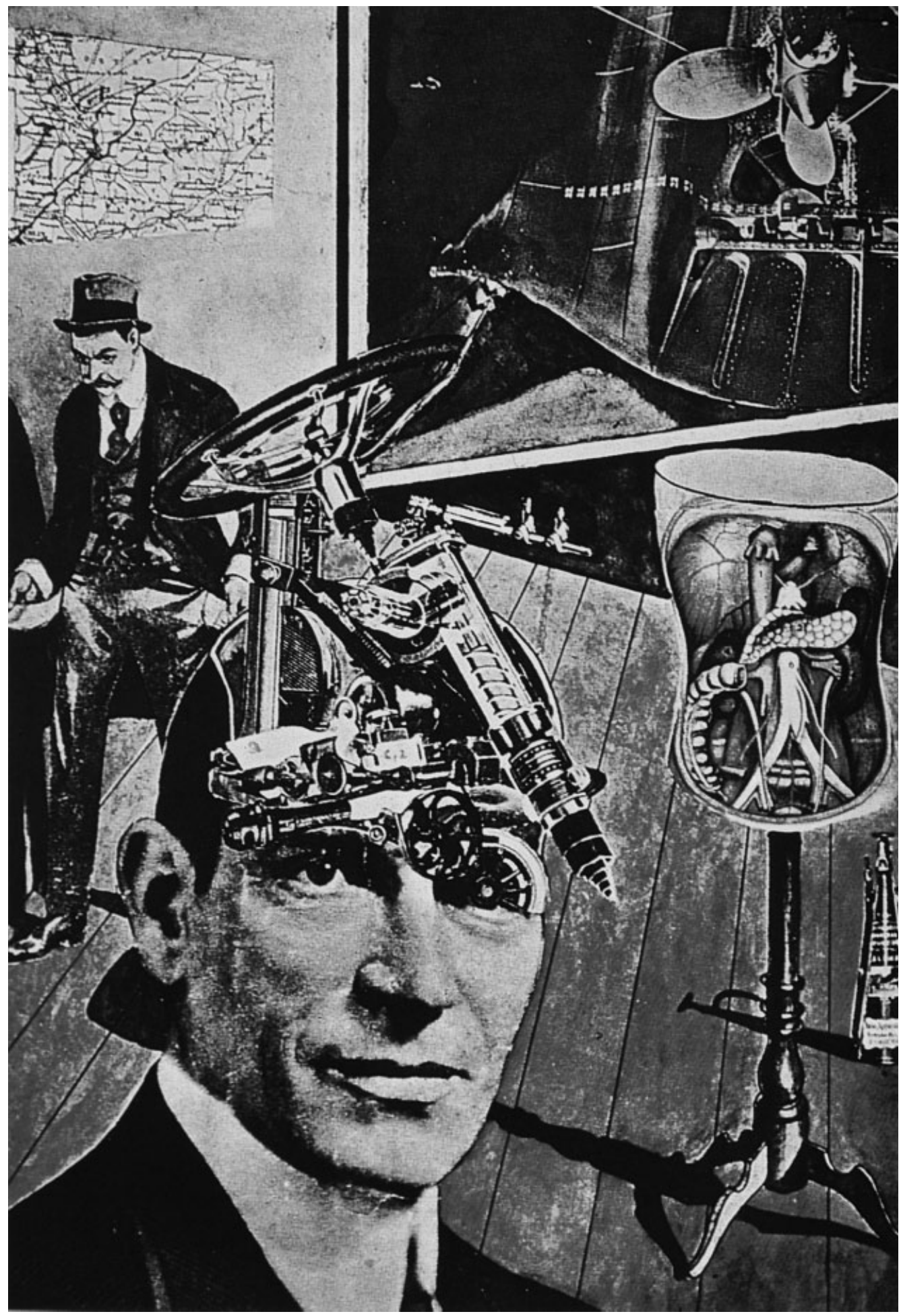

2.5 Raoul Hausmann, Tatlin Lives at Home, 1920. Photomontage, $40.9 \times 27.9 \mathrm{~cm}$. Stockholm:

Moderna Museet. Photo: (C) 2007 Artists Rights Society (ARS), New York/ADAGP, Paris. 


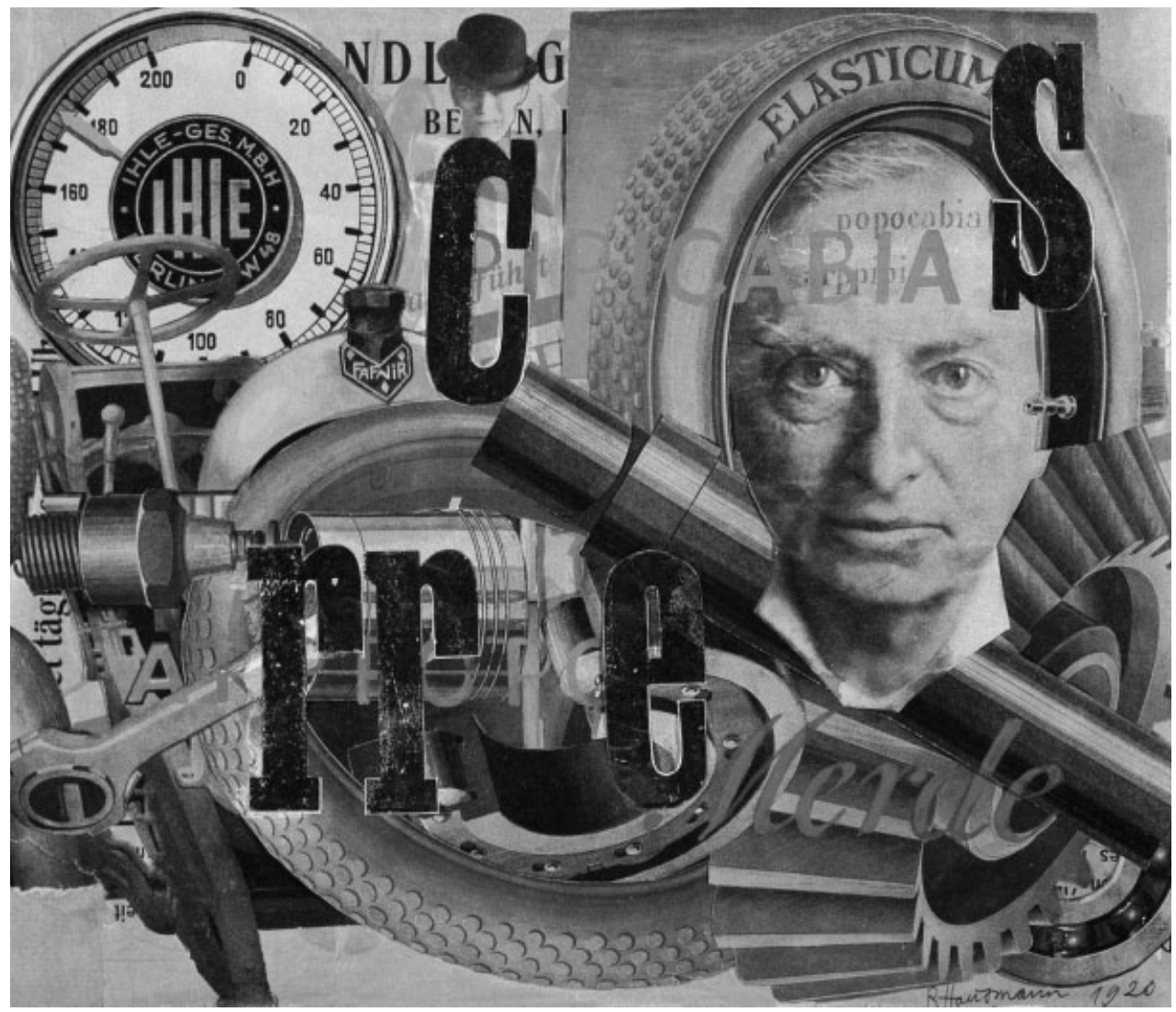

2.6 Raoul Hausmann, Elasticum, 1920. Collage and gouache reproduced on the title page of the First International Dada Fair catalogue, $31 \times 37 \mathrm{~cm}$. Berlin: Galerie Berinson. Photo: (C) 2007 Artists Rights Society (ARS), New York/ADAGP, Paris.

human - figures constructed out of elements transmitted through the mass media.

Instead of presenting actual portraits, both photomontages present allegorical representations of the dada artist, who recognizes his social construction and who uses both sound and vision to disrupt reality in an effort to imagine new modes of existence. As was later the case with $A B C D$, the contradictory associations produced by these images attempt to elicit a new more engaged spectator, one, moreover, who is aware humanity's power to turn reality into information. In Elasticum's wildly oscillating image field, for example, repeating circular forms (some parallel with the picture plane, some rotated into depth) serve to set off a chain of metaphorical associations, linking the cyborg's human head to a complex network of mechanical extensions: gears, tyres, a steering wheel, a pipe and a speedometer. Complicating and reinforcing this state of free association produced by the photographic materials, the fragments of text and nonsense words that Hausmann uses are juxtaposed in a way that violates all forms of normal syntax and sentence structure. Recalling Hausmann's various forms of sound poetry, as well as his interest in childhood states (suggested by the 
scatological 'pipicabia', 'popocabia' juxtaposition), the letters and letter strings help to evoke a reflexive and critical investigation of both sight and sound in terms of their social and psychological characteristics.

Elasticum's self-reflexive overtones, created by the nonsense texts and Hausmann's careful intertwining of images, letters and words, are further emphasized by the image's photomontage form, which potentially provokes what is today called 'institutional critique', a questioning attitude on the part of the work's audiences as to why Elasticum should be considered a work of art and - through this questioning attitude - the development of a reflexive awareness of the various institutional structures that allowed the photomontage to be perceived as a work of art in Germany in $1920 .^{58}$ In addition, the photomontage's selfreflexivity is also strengthened by Hausmann's appropriation of a human head with pronounced eyes, eyes that, because they meet the viewer's gaze, evoke a type of heightened self-conscious attentiveness that characterizes intimate communication. In this way, Elasticum's multiple forms of self-reflexivity potentially promote a meditation on selfhood, the photomontage's 'self-consciousness' - its various references to itself and to the idea of human subjectivity - inspiring its spectators to take up a similarly self-analytical attitude towards themselves. Suggesting the activities of driving, turning, babbling, urinating, defecating and the production of vast energies, Hausmann's photomontage thus shatters reality into a multiplicity of disconnected fragments, at the same time as it suggests through the fixed composition into which the disconnected bits of reality are then placed - that such fragments can be re-assembled to create new forms of hybrid identity better able to exist in the modern world. Although the new mode of identity suggested by Elasticum remains radically dissonant - an unwieldy composite of linguistic signs, mechanical parts and human bodily forms - oddly it seems to function as a viable totality: an image of a new form of human existence whose components can be freely chosen.

In addition to undermining a fixed sense of its subject's identity and promoting reflection on the subject's social construction, Elasticum also undermines a fixed sense of the identity of its author or creator. To make the photomontage, Hausmann began by appropriating the front cover of the catalogue of the First International Dada Fair, which was itself a reproduction - with additional text - of John Heartfield's photomontage Life and Times in Universal City at 12:05 Noon (1919), a photomontage that is sometimes identified as a collective creation of Heartfield and Grosz. (Parts of the 'original' cover can still be seen peeking out from behind the 'new' photomontage fragments that Hausmann used to assemble the image of the collaborative artist-cyborg.) By constructing his hybrid portrait of a dada artist out of an earlier photomontage one, moreover, that had a clear history of transformation and re-use in different contexts - Hausmann evokes a notion of authorship that is both collaborative and based on multiple forms of mechanical transmission and reproduction. Suggesting that art is the product of citation and effacement, Elasticum's appropriations thus reinforce the idea of the interactive nature of human identity as well as its transformations under the conditions of mechanical reproduction.

The idea that modern forms of identity result from the technologically mediated interaction of instinctual and social forces also seems to be the 
explicit theme of Tatlin Lives at Home. Staring directly out at the beholder, a steering column aggressively extending from its mechanized brain, the artist-cyborg's mind appears to radiate a series of shard-like planes containing a set of loosely associated appropriated images: a full view of a man turning out his pockets, a map of Pomerania with the island village where Hausmann and Höch allegedly discovered the technique of photomontage, a ship's stern with a propeller, a tailor's dummy, internal organs from a human body, and a fire extinguisher. Through this compositional device, the appropriated fragments can be read as the contents of the artist-cyborg's perception, at the same time as their associative qualities suggest that they could also be emblems representing his psyche, character, or standing in society. As is the case with the 'Picabia/Arp' portrait, the spatial discontinuities, the conflicting scales and multiple viewpoints, the strange juxtapositions of maps, diagrams and cut-away pictures all seem to relate to the central figure's mechanically grafted eye. Together, the work's photomontage form and its representational elements thus suggest the transformation of the world into different forms of information, and therefore into messages out of which new forms of existence may be produced. 'Tatlin' can thus be read as composed of - or even 'scripted' by - the elements that encircle his inquiring gaze. In addition, as is also the case with Elasticum, the various photomontage juxtapositions that constitute the representation of 'Tatlin' inhabiting his room create contradictory chains of metaphorical association - chains that do not permit the discovery of a single dominant reading. In this way, the ambiguity and multivalence of reality is retained - a sense of the world as exceeding the various representations that human beings make of it. And by evoking this state or condition, Tatlin Lives at Home suggests that modern human identity cannot be reduced to a single type or a unified mode of being.

\section{CYBORGS AND SEXUALITY}

As suggested by this brief investigation, Hausmann's representations of cyborgs and the theoretical and performative practices out of which they sprang in many ways confirm the model of avant-garde art developed by Peter Bürger and others since the mid-1970s. ${ }^{59}$ In accordance with the concept of the historical avant garde, Hausmann's art was montage-based (or 'non-organic'), appropriative and often collaborative. In addition, Hausmann's individual works were frequently heterogeneous (composed of a mixture of disparate materials), and his oeuvre as a whole demonstrated a wide variety of different styles, techniques and media. Furthermore, Hausmann's works clearly negate meaning and refer to the processes of their own construction. They thus challenged their spectators to examine the institutions that defined, supported, and legitimated bourgeois art in capitalist societies, provoking what Bürger and others have called 'institutional critique'. More specifically, Hausmann's cybernetic photomontages, poster poems and dada performances were doubly reflexive: they helped to inspire a simultaneous examination of art as an institution and representation as both a visual and a linguistic process. In addition, because of their non-traditional materials, their recourse to various forms and strategies derived from the mass media, their 
undermining of traditional signs of artistic originality, and their biting irony, they potentially provoked reflection on art's relative ineffectualness in modern bourgeois societies. Moreover, because of their representational aspects as well as their employment of strategies of chance and automatism, Hausmann's broad range of artistic activities seem radically open to the world in which they were made. Finally, because of the violence they evoke, Hausmann's works also seem profoundly mournful, that is, aware of - and attempting to work through - recent destruction, trauma and loss, a legacy of modern German society in general and the 1914-18 war in particular.

At the same time, the concept of the historical avant garde also obscures an important aspect of Hausmann's project: namely, his practice, through his representations of the cyborg, of imagining new forms of hybrid identity. For Bürger, avant-garde art continues aestheticism's emancipation of art from subject matter. ${ }^{60}$ Inspired by Walter Benjamin's concept of allegory, Bürger argues that avant-garde art negates the original contextual meanings of its various appropriated parts. ${ }^{61}$ Instead of drawing the viewer's or the reader's attention to what is actually represented, the parts of the avant-garde art work put the focus on the conceptual principles behind the work's construction. ${ }^{62}$ As a result, there is no room for subject matter in Bürger's account of the historical avant garde - a position that is taken over by even some of Bürger's most articulate critics: for example, Benjamin H.D. Buchloh. ${ }^{63}$

As has already been demonstrated, however, in addition to undermining the traditional concepts that defined and legitimated Western art in its various religious, courtly and bourgeois-modernist modes, Hausmann's performances and representations also dealt with a specific subject matter: namely, an imagining of new forms of hybrid identity. As noted above, Hausmann believed that homosexuality was a practice through which traditional forms of identity and society could be overcome. It thus comes as little surprise that some of his cybernetic self-portraits hint at alternative forms of sexuality. Double Portrait Johannes Baader and Raoul Hausmann (plate 2.7), a print of a photomontage, presents a good example of this subterranean homoeroticism that was part of Hausmann's politics of hybridity. The last in a series of at least three 'double portraits' created jointly by Hausmann and Baader during 1919 and early 1920, Double Portrait brings together two separate photographs of the artists, each nude from at least the waist up. As it is normally positioned, Hausmann appears right side up, reclining slightly and staring directly at the spectator with an ironic smirk on his lips and a monocle over his left eye. Baader, noticeably older and more grizzled than the youthful Hausmann, hangs upside down next to his comrade, their cheeks touching. Baader sports a beard, a more serious expression, and a less direct - more abstracted - stare.

The cybernetic aspects of the figures are downplayed but still present. Hausmann's monocle once again suggests technologically augmented vision. Furthermore, the positioning of the two figures violates traditional notions of the 'nature' of the human body; namely, its obedience to the laws of gravity, as well as the fact that, when vertical, human beings generally appear with their heads raised above the level of their feet. The positioning of the figures thus makes Baader seem like he has strange, supernatural powers; and in addition, because of their proximity to one another, it allows them to be read as parts of a 


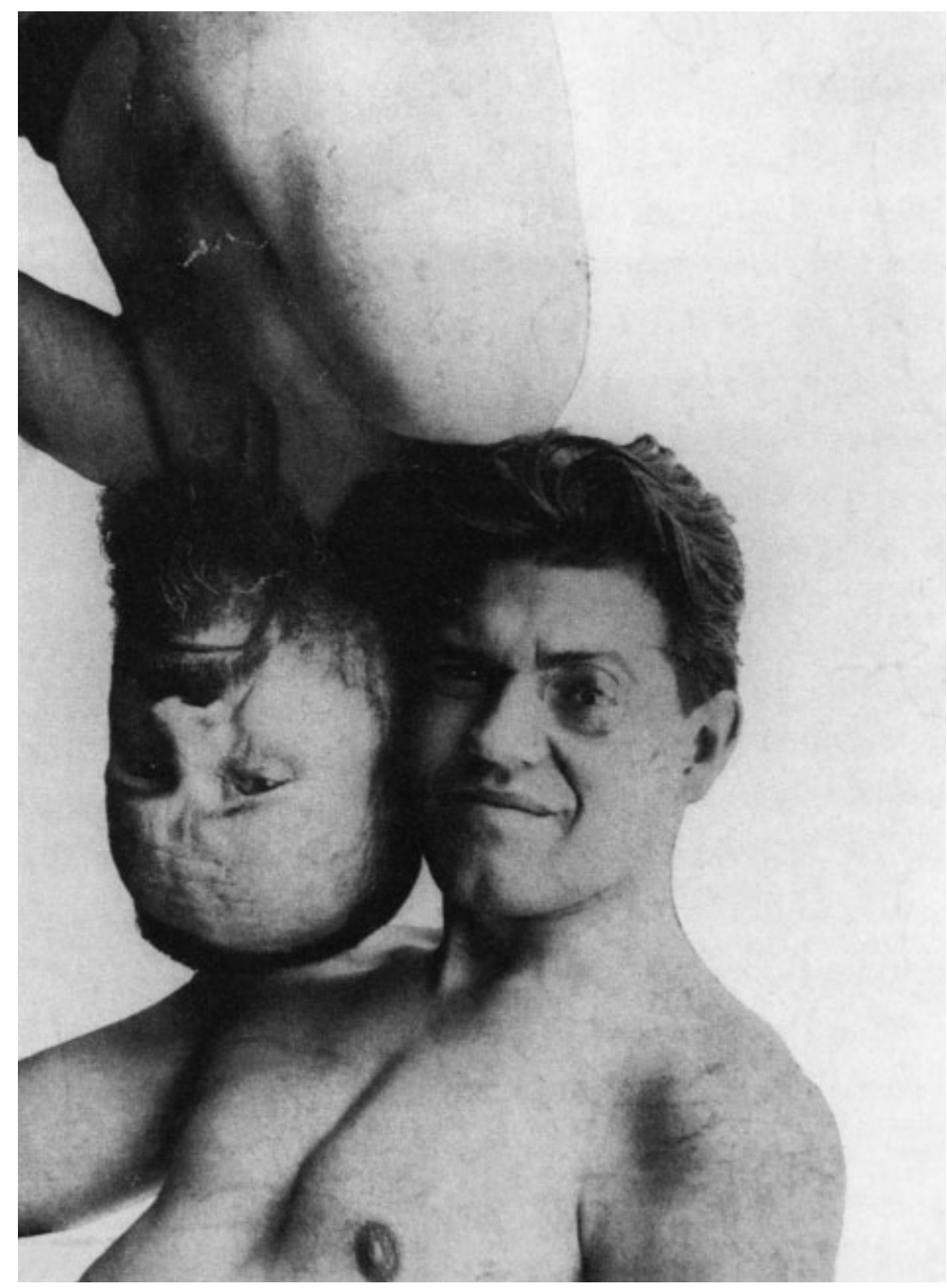

2.7 Johannes Baader and Raoul Hausmann, Double Portrait Johannes Baader and Raoul Hausmann, 1919/1920. Print of a Photomontage, $25.4 \times 15.8 \mathrm{~cm}$. Zürich: Kunsthaus Zürich. Photo: (C) 2007 Artists Rights Society (ARS), New York/ADAGP, Paris.

larger collective organism. Baader seems to sprout from the side and top of Hausmann's head, and the double portrait as a whole can be interpreted as a partial view of some strange hybrid creature. Given what appears in the image, it could be easily imagined that, if the edges of the print were extended, the two dada artists would appear enmeshed within an even larger collective of unnaturally merged bodies.

The double portrait, moreover, also evokes a certain homoeroticism that goes beyond the homosociality evoked by many of Hausmann's works. As Eve Kosofsky Sedgwick argues, in modern patriarchal societies, male homosociality - male bonding or, more generally, men promoting the interests of men - is opposed to 
male homosexuality: men having sexual relations with other men. Unlike female homosociality, which is generally perceived to be more continuous with female homosexuality, male homosociality is radically distinguished from male homosexuality. This is the case because compulsory male heterosexuality is necessary for the maintenance of patriarchal societies, while female homosexuality is generally perceived to be far less disruptive. ${ }^{64}$

In light of Sedgwick's definitions, Hausmann's portraits of 'Tatlin' and 'Picabia/Arp', which suggest shifting identities, also evoke male homosociality. They hint, in other words, that the male dada artists are like one another and thus have common interests. In addition, Hausmann's use of his comrades' names and earlier creations in these portraits also implies that his art is made with the help of other men. Double Portrait, on the other hand, goes much further than the other portraits discussed above in that the nakedness of the figures, their proximity to one another, and the emphasis that is placed on Hausmann's nipple (an erogenous zone) by its positioning along the bottom edge of the composite image together create erotic - even sexual - connotations. In addition, by presenting the two artists as a couple, and by playing off a traditional homosexual trope of an older man taking a younger man as his lover, the double portrait reinforces these homoerotic associations. ${ }^{65}$ Moreover, Hausmann's writings on the revolutionary potential of homosexuality - and thus the discursive network that he created that allows for a homosexual reading of this image - gives additional support to this interpretation. ${ }^{66}$ Finally, the increased attention that was being paid to homosexuality in the public sphere during the Weimar Republic - as well as the fact that Baader and Hausmann presented themselves in intimate contact with one other in all three of their double portraits - would also have strengthened the photomontage's explicitly homoeroticism. ${ }^{67}$ Given these connotations, Double Portrait thus seems to be the most radical of the photomontage portraits discussed in this article, since, unlike the merely homosocial portraits, it threatens a patriarchal world-view much more directly. Finally, Double Portrait is also reversible around its horizontal axis; either Hausmann's figure or Baader's figure could be positioned right side up. As such, the print evokes the form of a mass-produced object: namely, a playing card. And by recasting their conjoined images as an element in a larger game, Hausmann and Baader reinforce a sense of the mutability of human identity, a sense that is also created by the signs of both cybernetic augmentation and same-sex desire.

Because of its homoerotic significance, Baader and Hausmann's Double Portrait also manifests parallels with another concept of the cyborg: namely, the one developed by Donna Haraway since the mid-1980s. For Haraway, the cyborg defines a fundamentally hybrid form of human identity, one that undermines traditional distinctions between gender, race and class. ${ }^{68}$ According to Haraway, the cyborg, moreover, also breaks down three crucial distinctions that previously defined what it meant to be human: namely, the boundary between human and animal, ${ }^{69}$ the distinction between an organism and a machine, and the difference between the physical and the non-physical. ${ }^{70}$ Like Wiener, Haraway emphasizes that the cyborg is a creature that fundamentally functions through the reception, transmission and control of information; and, because the cyborg is a creature of information, it is subject to constant dispersal, transformation and exchange. 
In today's cybernetic societies, the

\begin{abstract}
'Integrity' or 'sincerity' of the Western self gives way to decision procedures and expert systems .... No objects, spaces, or bodies are sacred in themselves; any component can be interfaced with any other if the proper standard, the proper code, can be constructed for processing signals in a common language. ${ }^{71}$
\end{abstract}

Moreover, like Wiener, Haraway emphasizes the fundamentally ambivalent nature of the cyborg and the global situation that it represents. ${ }^{72}$

Haraway's theorization, however, goes far beyond that of Wiener in her emphasis on the cyborg as the 'other' - the cyborg, in other words, as a homosexual, as a woman, as a person of colour, as an outsider, or as a monster. For Haraway, the manifestations of the cyborg as various forms of other stand in sharp contrast to traditional Western conceptions of male bourgeois, petty bourgeois, or even worker subjects in nineteenth- and early-twentieth-century societies. Because the cyborg as other reveals the effects of patriarchal and nationalist domination as well as alternative modes of existence formed in resistance to technological exploitation and coercion, it discloses the cyborg's libratory political potential. Creatures of both 'imagination and material reality', ${ }^{73}$ these cybernetic outsiders make 'very problematic the statuses of man or woman, human, artefact, member of a race, individual entity, or body'. ${ }^{4}$ And such cyborgs become, for Haraway, important symbols of non-coercive hybrid identity, 'a kind of disassembled and reassembled, postmodern collective and personal self . ${ }^{75}$ They are figures, in other words, that suggest the collaborative nature of human identity - the fact that human self-understanding always exists in a dialectic with multiple conceptions of collective or group belonging. In addition, they suggest the 'limits of identification'; namely, that because of forces such as the unconscious and ideology, human self-understanding is always partial and that to best survive as a 'self' in today's societies, it is necessary to recognize one's multiple affiliations. ${ }^{76}$ Such cyborgs reveal an understanding of both self and society that tolerates - even welcomes - difference; an understanding that does not insist on a common origin or nature, let alone a master narrative or theory. ${ }^{77}$

By suggesting that Double Portrait evokes aspects of Haraway's concept of the cyborg, I do not wish to suggest that the concept of identity that inspired Hausmann's representations of the cyborg was as radical as the one that Haraway developed, but rather that, in terms of his view of sexuality, Hausmann's understanding of human identity was more advanced than that of Wiener and much closer to a contemporary radical view of subjectivity. Indeed, the Berlin dada artist whose works dovetail most closely with Haraway's thinking is Hannah Höch, who, throughout the 1920s and early 1930s, made photomontages that explicitly undermined clear distinctions between different genders and races as well as the divide between human and animal. ${ }^{78}$ At the same time, however, it is important to locate Hausmann's visualization of the cyborg as a central moment in the development of the concept of the cyborg as a form of hybrid identity, one that, from the vantage point of today, seems to be conceptually situated between Wiener's more mechanistic view of the cyborg on the one hand and Haraway's radically postmodern view on the other. Although Hausmann remains closer in 
most regards to Wiener than he does to Haraway, his understanding of sexuality was explosively radical for his time.

Moreover, by arguing that Double Portrait stands in a tradition of representation that celebrates gay male sexuality - a tradition that anticipates, for example, the radical homoerotic photography of Robert Mapplethorpe between the 1970s and the 1990s - I do not wish to imply that later artists were necessarily cognizant of this subterranean homoeroticism in the works of some of the Berlin dada artists. However, as should be sufficiently clear by now, this hidden homoeroticism did indeed exist, and it was an aspect of a larger interest on the part of the Berlin dada group in a politics of hybrid identity, a politics for which the image of the cyborg became a frequently used allegorical figure. One of the overarching goals of this essay has been to suggest that the identity politics prominent in contemporary art since at least the 1990s finds important precursors in the subjects and practices of the historical avant garde. And while it is beyond the scope of this essay to examine other manifestations of the Berlin dada interest in hybridity, it is important here at least to acknowledge their existence. This interest can be seen, for example, not only in the works by Raoul Hausmann discussed above, but also in the focus on constructing racially hybrid figures that appears in the photomontages of Hannah Höch throughout the 1920s and early 1930s, an interest in ethnic hybridity that is later taken up in the photomontage practices of Romare Beardon in the 1960s and 1970s and, most recently, in those of Wangechi Mutu since 2001. It also appears in the focus on the subversion of gender identity so characteristic of dada and surrealist assemblage in the 1920s and 1930s, as well as in the 'corporeal sculpture' of such contemporary artists as Louise Bourgeois, Rona Pondick, Robert Gober, Kiki Smith, Charles Ray, and Jake and Dinos Chapman. That the artists of the historical avant garde anticipated both the radical subject matter of hybrid identity and the cybernetic understanding of the world characteristic of many artists practising today in no way diminishes the radicality and importance of contemporary art production. Instead, it simply shows that the strategies of representation that emerged after the 1914-18 war have yet to reveal their full potential.

\section{Notes}

Earlier versions of this essay were presented at Columbia University (2006), Northwestern University (2005), Swarthmore College (2002), The Centre for Advanced Study in the Visual Arts (2001), University of Pennsylvania (2000), and the College Art Association Annual Conference (2000). I am indebted to my various commentators and interlocutors at these talks. I would also like to thank the anonymous reviewers for Art History, as well as Alex Potts, for their generous and insightful comments. Unless otherwise noted, all translations are my own.

1 Since the 1990s, a number of studies have been published that deal with the subjects of Berlin dada, 'subjects' being here understood as a set of characteristic figures, objects and settings that are common to a group of artists and that have been invested with commonly held meanings and concepts. See, for example, Maud Lavin, Cut With the Kitchen Knife: The Weimar Photomontages of Hannah Höch, New Haven, 1993; Maria Makela, 'The Misogynist Machine: Images of Technology 
in the Work of Hannah Höch', in Katharina von Ankum, ed., Women in the Metropolis: Gender and Modernity in Weimar Culture, Berkeley, 1997, 106-127; Brigid Doherty, "See: We Are All Neurasthenics!' or, The Trauma and Dada Montage', Critical Inquiry, 24:1, Autumn 1997, 82-132; Brigid Doherty, 'Figures of the Pseudorevolution', October, 84, Spring 1998, 65-89; and Sherwin Simmons, 'Advertising Seizes Control of Life: Berlin Dada and the Power of Advertising', Oxford Art Journal, 22:1, 1999, 119-46.

2 The terms 'hybrid' and 'hybridity' have been rightly criticized by post-colonial theory for their suitability to racist discourse as well for their assumption of originally 'pure' or unmixed states, generally of a racial, sexual, or national nature. See, for example, Nezar AlSayyad, ed., Hybrid Urbanism: On the Identity Discourse and the Built Environment, Westport, CT, 2001, and in particular, 1-18. As it is used here, the term 'hybrid identity' instead indicates a cybernetic conception of the subject. This conception of human identity defines it as a process in which different forms of self-identification or allegiance encounter and transform one another without any one of them becoming dominant. In its more radical forms, which appear in some, but not all, of Hausmann's productions, hybrid identity defines not only 'race', 'gender', 'class' and 'nation' to be nonbinding, non-essential properties, but also acknowledges the broader interconnections that human beings share with animals, machines and their environments.

3 Chris Hables Gray, ed., The Cyborg Handbook, New York and London, 1995, 29.

4 See Donna J. Haraway, 'A Cyborg Manifesto: Science, Technology, and Socialist-Feminism in the Twentieth Century' (1985/91) in Haraway, Simians, Cyborgs, and Women: The Reinvention of Nature, New York, 1991, 149-81.

5 Norbert Wiener, Cybernetics, or, Control and Communication in the Animal and the Machine, New York, 1948, 19.

6 Wiener, Cybernetics, 10.

7 Wiener, Cybernetics, 13.

8 Wiener, Cybernetics, 11, 31.

9 Norbert Wiener, The Human Use of Human Beings: Cybernetics and Society, revised edn, Garden City, NY, 1954, 162.

10 Wiener, Cybernetics, 37.

11 Wiener, The Human Use of Human Beings, 162.

12 On the dialectic between self and enemy in Wiener's thinking, see Peter Galison, 'The Ontology of the Enemy: Norbert Wiener and the Cybernetic Vision', Critical Inquiry, 21:1, Autumn 1994, 265.

13 Wiener, The Human Use of Human Beings, 58.

14 Wiener, The Human Use of Human Beings, 96.

15 Wiener, The Human Use of Human Beings, 96-102.
16 Hindenburg is depicted in Hausmann's written work as a creature of appetites, living his life in the context of a public eatery. See Raoul Hausmann, 'Warum Hindenburg 'nen Vollbart trägt', in Hausmann, Bilanz der Feierlichkeit: Texte bis 1933, München, 1982, Bd. 1, 134-6.

17 For a literary description of the conventional mind, see Hausmann's 'Lob des Konventionellen' in Hausmann, Sieg Triumph Tabak mit Bohnen: Texte bis 1933, München, 1982, Bd. 2, 48-50.

18 Despite the utopian ideas connected to the mass media during the Weimar Republic, the new institution of cinema received much criticism in Germany in the decades following its invention; see, for example, the critical articles collected in Jörg Schweinitz, Prolog vor dem Film: Nachdenken über ein neues Medium 19091914, Leipzig, 1992, 55-143. Although much of the negative film criticism came from bourgeois and traditionalist critics, left-wing critics and theorists also expressed reservations: see, for example, Siegfried Kracauer, The Mass Ornament: Weimar Essays, trans. Thomas Y. Levin, Cambridge, MA, 1995, 281-328. Walter Benjamin also notes both the benefits and the risks of the new mass media in a number of his most important essays: see, for example, Walter Benjamin, 'A Short History of Photography' (1931) in Alan Trachtenberg, ed., Classic Essays on Photography, New Haven, 1980, 199-216, as well as Benjamin, 'The Work of Art in the Age of Mechanical Reproduction' (1935-39) in Benjamin, Illuminations, trans. Harry Zohn, New York, 1969, 217-51.

19 For Hausmann's worries about the scientific and technological extension of human perception, see Hausmann, Bilanz der Feierlichkeit, 15.

20 See Brigid Doherty's compendium and analysis of the Berlin dadaists' conflicting accounts of the development of photomontage. Brigid Doherty, 'Berlin', in Leah Dickerman, ed., Dada: Zurich, Berlin, Hannover, Cologne, New York, Paris, Washington, 2005, 90-9.

21 Doherty, 'Berlin', 93-5.

22 Doherty, 'Berlin', 90.

23 On the history and significance of the soldier portraits in Germany, see Elizabeth Otto, 'Figuring Gender: Photomontage and Cultural Critique in Germany's Weimar Republic', $\mathrm{PhD}$ diss., Ann Arbor, 2003, 19-55.

24 Klaus Theweleit, Male Fantasies, Volume 1: Women, Floods, Bodies, History, trans. Stephen Conway, Erica Carter and Chris Turner, Minneapolis, 1987; and Klaus Theweleit, Male Fantasies, Volume 2, Male Bodies: Psychoanalyzing the White Terror, trans. Erica Carter, Chris Turner and Stephen Conway, Minneapolis, 1989.

25 See, for example, Hal Foster, 'Armor Fou', October, 56 Spring 1991, 65-97, and in particular, 64, 81-6.

26 See the examples collected in Robert Bosshard, Ute Eskildsen and Robert Knodt, Erinnerung an die 
Dienstzeit: Fotografien der Jahrhundertwende, Essen, 1993.

27 See Raoul Hausmann 1886-1971: Der Deutsche Spiesser Ärgert Sich, Berlin, 1994, 283.

28 Raoul Hausmann, 'Photomontage' (1931), trans. Joel Agee, in Christopher Phillips, ed., Photography in the Modern Era: European Documents and Critical Writings, 1913-1940, New York, 1989, 178-9.

29 Wiener, Cybernetics, 16.

30 In addition, the Czech banknote possibly refers to performances by Hausmann and Kurt Schwitters in Prague on 6 and 7 September. See Hannah Höch, 'A Glance Over My Life' (1958), trans. Peter Chametzky, in Lavin, Cut with the Kitchen Knife, 211-15. See also Raoul Hausmann 1886-1971, 283.

31 The ' $\mathrm{s}$ ' and the ' $\mathrm{z}$ ' recall the typography of fmsbw (1918). The row of letters as a whole, however, corresponds neither to fmsbw nor to OFFEAH (1918), the other surviving example of Hausmann's poster poems. This suggests that Hausmann created additional poster poems that have been lost. See Raoul Hausmann 1886-1971, 162.

32 Raoul Hausmann, Am Anfang war Dada, Gießen, 1980, 46.

33 For an excellent account of the similarities and differences between various forms of experimental poetry in the early decades of the twentieth century, see Richard Sheppard, Modernism-Dada-Postmodernism, Evanston, 2000, 101-144.

34 See John D. Erickson, Dada: Performance, Poetry, and Art, Boston, 1984.

35 For examples of the much more coherent poetry of the Italian futurists, see Willard Bohn, ed., Italian Futurist Poetry, Toronto, 2005. Sheppard also distinguishes the 'revisionist' poetry of the Italian futurists from the 'radical' poetry of Hausmann and other dada poets; see Sheppard, Modernism-Dada-Postmodernism, 125-31. On zaum poetry see, John J. White, Literary Futurism: Aspects of the First Avant-Garde, Oxford, 1990, 250-7. On the semantics of the zaum poets, see Gerald Janecek, Zaum: The Transrational Poetry of Russian Futurism, San Diego, 1996.

36 Raoul Hausmann, Am Anfang, 46. On Hausmann's interest in synesthesia and the broadening of sense perception, see Eva Züchner, 'Quellen der Revolte', in Raoul Hausmann 1886-1971, 286-7.

37 Jörg Drews, 'Die Stellung der Zunge im Gaumen: Tonbänder mit phonetischen Dichtungen Raoul Hausmanns' in Kurt Bartsch and Adelheid Koch, eds, Raoul Hausmann, Vienna, 1996, 258. Hausmann's poems are available on Poèmes Phonetiques, a compact disc produced by the Musée Départemental d'art contemporain de Rochechouart.
38 Kurt Schwitters, Ursonate, Mainz, Wergo Schallplatten $\mathrm{GmbH}, 1993$, compact disc.

39 The psychological concerns of dada art have received significant treatment in a number of recent studies. Doherty discusses Berlin dada in light of neurasthenia, shell shock and Sándor Ferenczi's writings on war neurosis. See Doherty, "See: We Are All Neurasthenics!' Amelia Jones productively connects neurasthenia and war neurosis to New York dada: see Amelia Jones, Irrational Modernism: A Neurasthenic History of New York Dada, Cambridge, MA, 2004.

40 Hans Richter, Dada: Art and Anti-Art, trans. David Britt, London, 1965, 139.

41 See Richard Huelsenbeck, 'Dada Tours' in Anton Kaes, Martin Jay and Edward Dimendberg, eds, The Weimar Republic Sourcebook, Berkeley, 1994, 486-7; Huelsenback, Memoirs of a Dada Drummer, Berkeley, 1991, 67-71; Hannah Höch, 'A Glance Over My Life', in Lavin, Cut With the Kitchen Knife, 211-15, and in particular, 212-13; and Walter Mehring, Berlin Dada: Eine Chronik mit Photos und Dokumenten, Zürich, 1959, 46. See also Richter's description of Schwitters performing his Ur Sonata in Richter, Dada: Art and Anti-Art, 142-3; Karin Füllner, Dada Berlin in Zeitungen: Gedächtnisfeiern und Skandale, Siegen, 1986; and Hanne Bergius, 'Dada Triumphs!' Dada Berlin, 1917-1923, Artistry of Polarities, trans. Brigitte Pichon, New Haven, 2003, 27-9, 35-6 and 64-9.

42 On Hausmann's sound poetry, see Karl Riha, 'fmsbwtözäu pgiv-..?mü: Raoul Hausmanns optophonetische Poesie', in Bartsch and Koch, eds, Raoul Hausmann, 31-44; and Jörg Drews, 'Die Stellung der Zunge im Gaumen: Tonbänder mit phonetischen Dichtungen Raoul Hausmanns', in Bartsch and Koch, eds, Raoul Hausmann, 256-9. Hausmann claims that he was aware of neither Ball's abstract poetry nor that of the zaum poets until 1920; see Janecek, Zaum, 210.

43 Wiener, The Human Use of Human Beings, 15-27, and in particular, 26-7.

44 Wiener, The Human Use of Human Beings, 57, 167.

45 On Jüng, Gross and The Free Street [Die freie Strasse], see Hanne Bergius, Das Lachen Dadas, Giessen, 1989, 66-89. On Gross's psychological theories and their influence on Hausmann, see Jennifer E. Michaels, Anarchy and Eros. Otto Gross' Impact on German Expressionist Writers: Leonard Frank, Franz Jung, Johannes R. Becher, Karl Otten, Curt Corrinth, Walter Hasenclever, Oskar Maria Graf, Franz Kafka, Franz Werfel, Max Brod, Raoul Hausmann, and Berlin Dada, New York, 1983, 35-55, 167-75; and Sheppard, ModernismDada-Postmodernism, 191-2. See also Roy F. Allen, Literary Life in German Expressionism and the Berlin Circles, Ann Arbor, 1972, 58, 131, 246. 
46 See Otto Gross, 'Vom Konflikt des Eigenen und Fremden', Die Freie Strasse, 4, 1916, reprinted in Bergius, Das Lachen Dadas, 71-3. See also Gross's essays, 'Die Einwirkung der Allgemeinheit auf das Individuum' (1913), 'Anmerkung zu einer neuen Ethik' (1913), and 'Notiz über Beziehungen' (1913), reprinted in Christina Jung and Thomas Anz, eds, Der Fall Otto Gross: Eine Pressekampagne deutscher Intellektueller im Winter 1913/ 14, Giessen, 2002, 159-69.

47 On Hausmann's politics and his interest in synthesizing Gross's radical psychology with 'anarcho-communist' thought, see Sheppard, Modernism-Dada-Postmodernism, 330-4.

48 'This most inner core of the revolution - the resignation of the male spirit and of the onesided male drive for order - must lead, by means of a complete dissolution of the existing pettybourgeois moral sexual relations, to the creation of a new community, and concurrently with the realization of the maxim, "Everyone according to their abilities, everyone according to their needs", eventually to a new justice and truth. The exploding point lies in the sexual as well as the economic. In the sexual, a revolution has still not begun, and we experience that, for example, in many cities in Russia, the male monogamous family is sublated, and in its stead, women are subjugated to a nearly monopoly-like concept of property. Here only a clarification of sexual relations will lead to liquidating technological developments. The Communist Manifesto promotes the female community and refers to the fact that the family - and consequently the dominant patriarchal morality - was of little value to the proletariat. It is, however, necessary that one proceeds here not only in general according to the classes, but also according to the fundamentals of human existence. The child's sexual complex shows us the way to this.' Hausmann, Bilanz der Feierlichkeit, 51-2. See also Hausmann, 'Der Besitzbegriff in der Familie und das Recht auf den eigenen Körper', in Hausmann, Bilanz der Feierlichkeit, 34-8, and in particular, 37-8.

49 Hausmann, Bilanz der Feierlichkeit, 50-1.

50 'In young friendships, for example, homosexuality is apparent as a natural drive of human beings. Nearly every child has homosexual tendencies - tendencies that do not derive from its strategies of accommodation to the family. The bourgeois family scorned homosexuality and directed the sexual complex towards either masculine or feminine poles. The child is a highly instinctually developed form of human being. Homosexuality is not only present simply before and during puberty. In its wavering over the "authentic" gender roles, homosexuality is characteristic of the human being in general. The expansion of the sexual formation of human beings through homosexuality is repressed by the Christian romantic point of view during the family upbringing. Just as the forced compression of sexuality in monogamy was invented primarily as a means to simplify male domination tactics vis-à-vis women and was for generations continued thoughtlessly, so the essence of monogamy was pushed into dissolution through this mechanization. The secret male sexual form, which was needed for the continuation of patriarchal society, crippled the female drive to organization and society in its opposition to women, so that we only know the developmental forms of the mother or the prostitute or some lesbians, which cannot be considered in the context of the species development of the female spirit.' Hausmann, Bilanz der Feierlichkeit, 52.

51 'The formation of a female society, which leads to a new promiscuity and, in connection with this mother's law (as opposed to the patriarchal family law of male imprint), is most intimately connected to the reconstruction of bourgeois society through communism. The property concepts, which until now have been prized as sexual fidelity, have proven to be comfortable exploitation lies on the part of men. These concepts reduce women to prostitutes in more or less calculable forms; however, these concepts do not do justice to actual female sexuality, neither in the case of the mother, nor in the case of the free woman. The expansion of petty-bourgeois anarchist individualism (which requires taking possession of things in order to be able to represent property in the first place) into communism will point to that which is inalienably characteristic of male as well as female sexuality. The family as an instrument of coercion will be transformed into groups, relationships, and elective families through the transformation of women from their hitherto only male-determined and male-oriented sexuality to a truly female one, one whose essence is able support friendship, camaraderie, and adherents (in other forms), just like the hitherto male mode of sexual behaviour [Sexualverhalten]. The end of the subjugation of women will show that women are perhaps more strongly qualified than men to create moral values and social organization - only they will able to do this in a less "simple" way than men. Law and moral concepts, the so-called "truths" of men, must be totally destroyed; and they will show themselves as injustice and lies - precisely because of their simplifying and exclusionary aim to subjugate everything. The evaluation of an existence in contradiction will be set up by women, because women are actual, real in opposition to the idealizing gestures of men, who have grasped only some of the laws that direct life. The so-called mendacity of women will be transformed at a new stage of development into an ability to realize, an ability that previously was forced to appear as a lie because 
of the male will to do violence. Today, "true" men stand up for the dissolution of the property rights of men over women and for a transformation of the family of little worth as much as for the economic communist society, which runs parallel with an expansion of the sexual outlook.' Hausmann, Bilanz der Feierlichkeit, 52-4.

52 On the contradictions between Hausmann's professed beliefs and his actions towards Hannah Höch, see, for example, Lavin, Cut with the Kitchen Knife, 26-9; and Karoline Hille, Hannah Höch und Raoul Hausmann: Eine Berliner DadaGeschichte, Berlin, 2000, and in particular, 130-6.

53 See, for example, Raoul Hausmann, 'Club Dada. Berlin 1918-20' (1958), trans. J. M. Ritchie, in Paul Raabe, ed., The Era of German Expressionism, Woodstock, 1985, 225-7.

54 See Brigid Doherty, 'Figures of the Pseudorevolution', 72, 77.

55 According to Timothy Benson, despite their avowed interest, the dada artists knew little of Tatlin's art in 1920. Instead, they had received most of their information by reading Konstantin Umanski's article, 'Neue Kunstrichtungen in Rußland: I. Der Tatlinismus oder die Maschinenkunst', in Der Ararat, 1:1, January 1920. See Timothy O. Benson, Raoul Hausmann and Berlin Dada, Ann Arbor, 1987, 186.

56 Raoul Hausmann quoted in Benson, Raoul Hausmann and Berlin Dada, 186.

57 On the Berlin dada artists' interest in Henry Ford, see Doherty, 'Berlin', 93.

58 On the concept of institutional critique, see Peter Bürger, Theory of the Avant-Garde, trans. Michael Shaw, Minneapolis, 1984, 12-13, 22, 49. See also Benjamin H.D. Buchloh, 'Conceptual Art 1962-1969: From the Aesthetic of Administration to the Critique of Institutions', October, 55 Winter 1990, 105-143.

59 See Bürger, Theory of the Avant-Garde. Bürger's theory of the avant garde has had a significant impact on modern and contemporary art history since its publication. In the United States alone, important historian-critics like Donald Kuspit, Benjamin H.D. Buchloh and Hal Foster have all cited and developed Bürger's concepts. In particular, Bürger has been criticized for his devaluation of 'neo-avant-garde' art of the post war period. See Benjamin H.D. Buchloh, 'The Primary Colours for the Second Time: A Paradigm Repetition of the Neo-Avant-Garde', October, 37 Summer 1986, 41-52; and Hal Foster, 'What's Neo About the Neo-Avant-Garde?', October, 70 Fall 1994, 5-32. In addition, Bürger has also significantly changed his original evaluation of neoavant-garde art. See Peter Bürger, 'Letter to JeanFrançois Chevrier', in Catherine David and JeanFrançois Chevreir, eds, Politics, Poetics: Documenta $X$, the Book, Amsterdam, 1997, 379-80; see also Peter Bürger, 'Im Schatten von Beuys', Kunstforum, 90, July-September 1987. The criticisms of this essay - that Bürger's theory of the avant garde obscures a radical politics of hybrid identity-have not been made before, nor has Bürger altered his theory in a way that would render these criticisms invalid.

60 Bürger, Theory of the Avant-Garde, 49

61 Bürger, Theory of the Avant-Garde, 69. Bürger derives this argument from a particular passage in Benjamin's book on the German Trauerspiel. As Benjamin puts it, 'If the object becomes allegorical under the gaze of melancholy, if melancholy causes life to flow out of it and it remains behind dead, but eternally secure, then it is exposed to the allegorist, it is unconditionally in his power. That is to say it is now quite incapable of emanating any meaning or significance of its own; such significance as it has, it acquires from the allegorist.' Walter Benjamin, The Origin of German Tragic Drama (1925/1928), trans. by Josh Osborne, New York, 1990, 183-4. Although the passage does suggest that the allegorist eliminates the original meaning of the allegorical fragment and gives it a new one, Benjamin's actual interpretive practices raise questions as to how closely he followed this principle.

62 Bürger, Theory of the Avant-Garde, 79-80.

63 Buchloh, for example, attacks Joseph Beuys for his representational use of readymades - i.e., his use of real-world objects to stand for ideas - a use, according to Buchloh, that is a radical perversion of Duchamp's original readymade practices. See Benjamin H.D. Buchloh, 'Twilight of the Idol', Artforum, 18: 5, January 1980, 35-43, and in particular, 39-40. A reliance on the same citation from Benjamin also underlies Craig Owens's contention that postmodern works of art replace the meanings of the fragments that they appropriate. See Craig Owens, 'The Allegorical Impulse: Toward a Theory of Postmodernism' in Craig Owens, Beyond Recognition: Representation, Power, and Culture, Berkeley, 1992, 52-87, and in particular, 54.

64 Eve Kosofsky Sedgwick, Between Men: English Literature and Male Homosocial Desire, New York, 1985, 1-5.

65 For a good example of this trope, see Plato's Symposium. Plato: Symposium, trans. Robin Waterfield, New York, 1994.

66 I am indebted to Gavin Butt for the idea of a preexisting discursive network - 'gossip', for Butt helping to support a homosexual reading of a work of art. See Gavin Butt, Between You and Me: Queer Disclosures in the New York Art World, 19481963, Durham, 2005, in particular 5-9. Although Hausmann's discussions of homosexuality are more direct and explicit than some of the discursive resources upon which Butt relies, like Butt's discursive source materials, Hausmann's writings help to support and legitimate a homosexual reading of some of his art works. On Hausmann's understanding of the revolutionary 
potential of homosexuality, see notes 48 and 50 above.

67 For reproductions of the other two double portraits, see Raoul Hausmann 1886-1971, 50-1. On the growing discourse about homosexuality in Germany since the 1860 s, see James D. Steakley, The Homosexual Emancipation Movement in Germany, New York, 1975.

68 Haraway, Simians, Cyborgs, and Women, 155.

69 Haraway, Simians, Cyborgs, and Women, 151.

70 Haraway, Simians, Cyborgs, and Women, 153.

71 Haraway, Simians, Cyborgs, and Women, 163.
72 Haraway, Simians, Cyborgs, and Women, 154. 73 Haraway, Simians, Cyborgs, and Women, 150. 74 Haraway, Simians, Cyborgs, and Women, 178. 75 Haraway, Simians, Cyborgs, and Women, 163. 76 Haraway, Simians, Cyborgs, and Women, 157. 77 Haraway, Simians, Cyborgs, and Women, 177.

78 On Höch's bisexuality and her use of photomontage to undermine traditional forms of gender identity, see Lavin, Cut With the Kitchen Knife, 185-204, and in particular, 188-90. 